\title{
norden
}

Nordic Council of Ministers

Ved Stranden 18

DK-1061 Copenhagen K

www.norden.org

NORDISKE ARBEJDSPAPIRER

NORDIC WORKING PAPERS

\section{Scoping study on financing adaptation-mitigation synergy activities}

Julia Illman, Mikko Halonen, Pasi Rinne, Saleemul Huq and Svein Tveitdal

NA2013:902

http://dx.doi.org/10.6027/NA2013-902

This working paper has been published with financial support from the Nordic Council of Ministers. However, the contents of this working paper do not necessarily reflect the views, policies or recommendations of the Nordic Council of Ministers. 


\section{Table of contents}

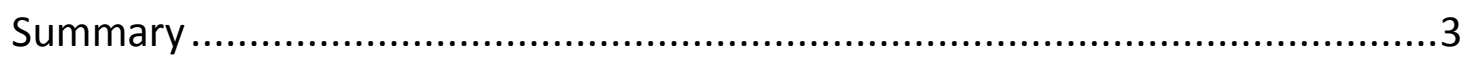

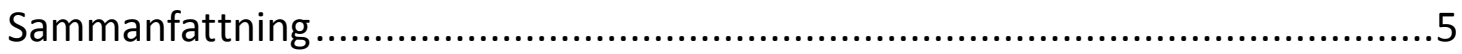

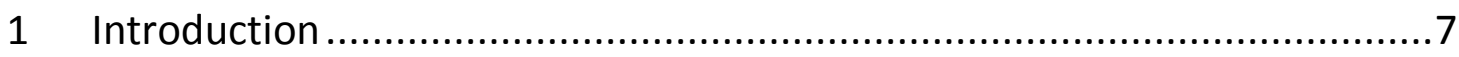

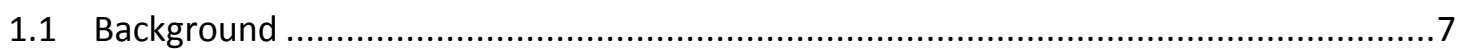

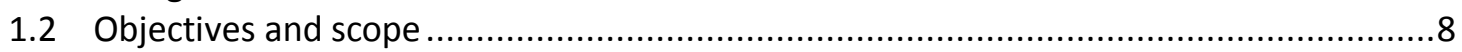

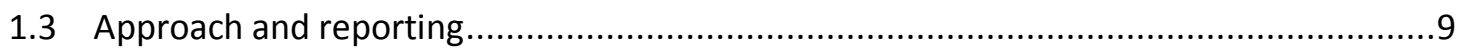

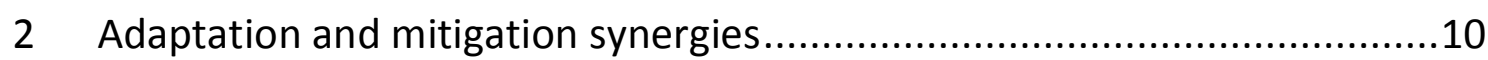

2.1 Background to climate policy - the balance between mitigation and adaptation ..........10

2.2 Defining adaptation and mitigation synergies .............................................. 11

2.3 Types of synergies between adaptation and mitigation ....................................

3 Opportunities to improve financing on adaptation and mitigation

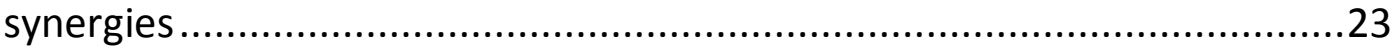

3.1 Assessing the importance and size of the synergies - next steps..............................23

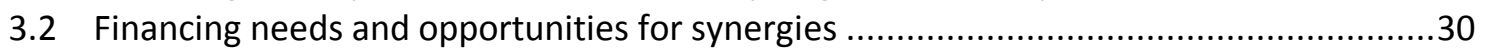

3.3 How to operationalize funding of synergies - challenges and opportunities? ................35

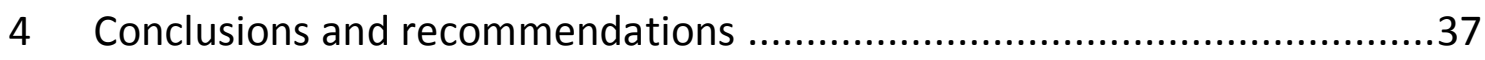

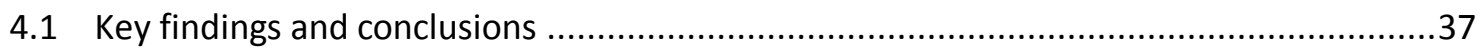

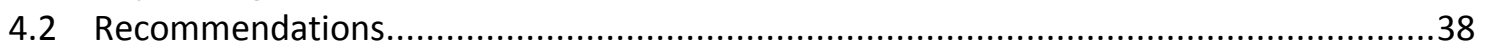

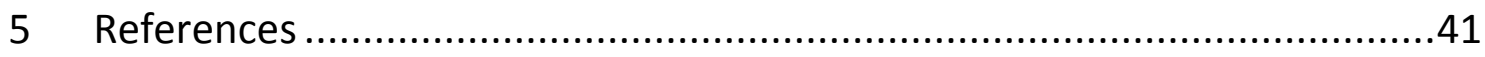

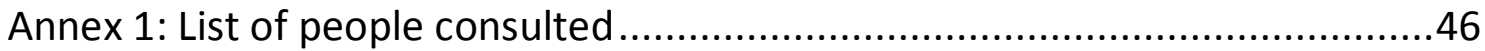

Annex 2. Overview of the global architecture of public finance .........................47

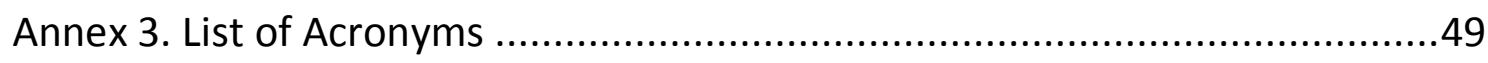

Annex 4: Presentation of the project team .....................................................51 


\section{Summary}

Emissions on a global scale continue to rise and impacts of climate change are already being felt in many parts of the world. Yet concrete action and required funding for climate change risk management is lagging behind the levels needed to support mitigation and adaptation in order to avoid dangerous levels of climate change. There is an urgent need to seek new funding sources and to ensure that the current and future funding is used in the most efficient and effective manner.

One potential way to address these needs is to systematically promote synergies and avoid tradeoffs among mitigation and adaptation actions. This could enable simultaneous prevention of further emissions increases guiding economies towards low/no-emission pathways as well as accelerating adaptation and required resilience building. This scoping study explores the opportunities and challenges related to promoting synergies and avoiding trade-offs from the perspective of climate finance.

Existing research has drawn attention to the differences between adaptation and mitigation as strategies to manage climate risks. Yet studies are increasingly beginning to view the two as complementary to each other. While the landscape of current research remains rather scattered and limited, examples that demonstrate promising potential for accommodating synergies have been identified in several sectors. These sectors include rather obvious candidates such as agriculture, forestry and land use which all play a key role in both mitigation and adaptation. In addition, this study has identified potential for synergies in the energy, infrastructure planning and construction, transportation, insurance and waste treatment sectors.

While no quantitative assessments have been made on the magnitude of the potential for synergies, three particular areas are expected to present opportunities. Developing countries with high (and/or rapidly increasing) emissions and major vulnerabilities are well placed to harness synergies. Promising sectors are those that have a lot of mitigation potential and that have been a focus of national level adaptation plans. In addition, development in urban areas offers ample opportunities to harness synergies in building and infrastructure development.

Synergies are offering solutions to more efficient, responsive and comprehensive climate policy. They can also result in co-benefits with other goals of sustainable development. Further research into mitigation and adaptation aspects is likely to broaden the spectrum of potential for synergies and trade-offs. The reviewed literature, and in particular, the experts consulted in this study recognize the potential of synergies as a promising area that merits further attention.

With regards to the climate finance landscape, current funding sources, channels and instruments are geared towards either mitigation or adaptation, primarily based on strict funding criteria of most funding organizations. The major part of climate funding to date has been channeled through project-based activities. During the scoping study, no funding instruments with explicit and systematic aims to harness synergies (or systematic screening projects/programmes and policies to avoid trade-offs) were identified. However, multiple stakeholders interviewed in this study acknowledge the potential for synergies and assume the existence of these to some extent in several of their activities. 
Developing countries are increasingly preparing national strategies that aim to integrate both mitigation and adaptation aspects into the development aspiration. This can be seen as a sign of slow but successful mainstreaming of climate change issues into various sectors and the development agenda. Entering an era of more programmatic and possibly "whole of government" approaches may allow better identifying and harnessing of synergies.

This study provides four recommendations. Firstly, it recommends that more empirical research on synergies is conducted to further define and concretize the benefits and challenges. Further research on existing cases, for example through piloting, will allow showcasing under which criteria and how synergies can be harnessed and trade-offs avoided in the best possible way. This will help tackle any concerns related to potential inefficiencies and to address other remaining challenges in for example project planning. Secondly, it is suggested that a review of the funding criteria of relevant climate funds is carried out. Criteria could be analyzed according to how possible synergies are currently addressed, reported and/or valued and more importantly, how the funding criteria might be adjusted to allow for funding of synergies. Reviewing the possibility and interest of existing funds to study their criteria and to analyze synergies (and trade-offs) in their existing portfolios, could serve as a reinforcing approach. Thirdly, it is recommended that the concept of synergies is linked with the climate mainstreaming agenda. Comprehensive mainstreaming of climate change into various sectors, policies and development plans will need to better understand the interlinkages between various mitigation and adaptation measures as well as interlinkages with other policy areas. This is a precondition for advancing from mainly project-based climate activities into more comprehensive, climate mainstreamed action. Finally, attention should be paid to opportunities to catalyze private sector climate action. As the role of the private sector will remain central in ensuring sufficient climate funding alongside efficient and effective implementation, its role in systematically harnessing any synergies must be well understood. The role of public climate finance remains catalytic but it is crucial in building enabling environments and capacities that guide private sector funding to mainstream mitigation and adaptation aspects in their business development and investment decisions in developing countries.

Nordic countries are well positioned to contribute to climate action in developing countries. The Nordic countries have representation in various climate funds and a joint position on the issue of synergies could be influential. The Nordic countries also have particular expertise in some sectors, which could serve developing countries in addressing their priority climate challenges including placing stronger focus on synergies. Learning from synergies and trade-offs in developing countries can also serve developed countries. Synergies could be seen as an opportunity for more comprehensive climate change action in the Nordic countries. In particular, there is an opportunity to increasingly move from stand-alone project-based climate action (whether adaptation or mitigation or the two combined) towards supporting broader, sector-wide and national-level action plans. Funding decisions could consider how countries are planning to address both mitigation and adaptation instead of looking at individual projects. Funding broader action plans could be more effective than pushing for separate initiatives that focus only on synergistic activities. 


\section{Sammanfattning}

På global nivå fortsätter utsläppen att stiga och effekterna av klimatförändringen märks redan på flera håll i världen. Emellertid släpar de konkreta åtgärderna och finaniseringen av hanteringen av klimatrisker efter. Det finns ett brådskande behov för att hitta nya finansieringskällor samt att garantera att den nuvarande finansieringen ändvänds på ett effektivt sätt. Ett potentiellt sätt att tillgodose dessa behov är att systematiskt främja synergieffekter och undvika kompromisser mellan begränsnings- och anpassningsåtgärder. Detta kan möjliggöra motverkandet av utökandet av utsläpp av de ledade ekonomiska makterna samt påskynda anpassningsarbetet. Denna avgränsade studie utforskar de möjligheter och utmaningar som berör främjandet synergieffekter och undvikandet kompromisser ur klimatfinansieringens synvinkel.

Befintlig forskning har uppmärksammat skillnaderna mellan anpassning och begränsning som strategier för att hantera klimatrisker. Trots detta har utredningar till allt högre grad börjat se dessa som komplement till varandra med klart identifierbara synergier. Emedan helhetsbilden på den nuvarande forskningen är splittrad och begränsad, påvisar exempel lovande potential på tillvaratagandet av synergier emellan flera sektorer. Bland dessa finns relativs typiska exempel så som jord- och skogsbruk och markanvändning. Denna studie har kunnat påvisa att synergier även förekommer $\mathrm{i}$ branscherna för energi, infrastruktur planering och byggande, transport, försäkring och avfallshantering.

Trots att inga kvantitativa bedömningar av synergierna har gjorts, visar det de tre utforskade ämnesområdena at ha märkbart potential för tillgodotagande av synergieffekter. Utvecklingsländer med höga eller stigande utsläpp och där tillhörande sårbarhet har goda möjligheter att tillgodota synergieffekter. Lovande sektorer sådana som har anpassningspotential och som har varit föremål för nationella anpassningsplaner. Slutligen erbjuder utveckling i städerna goda möjligheter för att utnyttja synergier inom bygg och infrastruktur. Utvecklingen i urbana miljöer erbjuder utmärkta möjligheter att tillvarata synergier i samband med byggande och utveckling av infrastruktur.

Där synergieffekter har identifierats, har dessa bidragit till effektivare, påtagliga och heltäckande klimat politik. De har också lett till sidovinster med andra mål för hållbar utveckling. Ytterligare forskning är sannolikt att bredda spektrumet av möjligheter till synergier och kompromisser. Den genomgångna litteraturen, och i synnerhet de intervjuade experterna i denna studie håller med om att potentialen av synergier är ett lovande område som förtjänar ytterligare uppmärksamhet.

Med avseende på helhetsbilden på klimatfinansieringen har utvecklingen skett snabbt och komplexiteten har ökat. De rådande finansieringskällorna och instrumenten är inriktade, antingen på begränsning eller på anpassning, och riktar sig främst på strikta finansieringskriterier. Den största delen av klimatfinansieringen har hittills kanaliserats via projektbaseradverksamhet. I samband med avgränsningen av studien, kunde inga finansieringsinstrument identifieras som explicit studerade föremål för synergier. Oavsett detta framhävde många olika aktörer som intervjuades i denna studie synergier mellan begränsning och anpassning.

I allt högre grad utarbetar utvecklingsländer nationella strategier som syftar till att integrera både begränsnings och anpassnings aspekter i utvecklingsarbetet. Detta kan ses som ett tecken på lång- 
sam men framgångsrik integrering av klimatförändringsfrågorna i olika sektorer och mer allmänt i utvecklingsagendan.

Denna studie ger fyra rekommendationer. För det första rekommenderas att mer empirisk forskning om synergier bedrivs för att ytterligare definiera och konkretisera de fördelar och utmaningar. Ytterligare forskning kommer sannolikt att påvisa hur synergier kan utnyttjas och hur kompromisser kan undvikas på bästa möjliga sätt. Detta kommer att bidra till att lösa problem med anknytning till potentiell ineffektivitet. För det andra föreslås att en översyn av finansieringskriterier för relevanta klimatfonder utförs. Kriterier skulle kunna analyseras utgående hur eventuella synergier för närvarande behandlas, redovisas och / eller värderas. För det tredje rekommenderas att begreppet synergier kopplas till klimat mainstreaming agendan. Omfattande integrering av klimatförändringen i olika sektorer, policyn och kräver ett bättre förstående av sambanden mellan olika begränsningsåtgärder och anpassningsåtgärder. Slutligen bör privata sektorns roll uppmärksammas. Privat sektorn kommer fortsättningsvis att ha en central roll i säkerställandet av tillräcklig klimatfinansiering samt effektivt genomförande av densamma.

Norden är väl positionerad för att bidra till klimatåtgärder i utvecklingsländer. De nordiska länderna är väl representerade i olika klimatfonder och har en gemensam ståndpunkt i frågan om synergier. Vidare har de nordiska länderna särskild kompetens inom sådana sektorer som skulle kunna bidra till att utvecklingsländer starkare fokuserade på synergier. Genom att de nordiska länderna aktivt arbetar för klimatmainstreaming kunde synergieffekter kunna ses som en möjlighet till att hitta mer omfattande klimatförändringslösningar. Speciellt finns det en möjlighet att förflytta fokus från ett projektbaserat tillvägagångssätt till ett mer heltäckande tillvägagångssätt. Finansiering av mer övergripande handlingsplaner kan visa sig vara mer effektivt än att driva separata initiativ som fokuserar bara på synergisfokuserade aktiviteter. 


\section{Introduction}

\subsection{Background}

While climate change mitigation has in the past years often received more attention in analysis and discussions related to climate funding (required amounts, types, channels, MRVs etc), adaptation funding is still at initial stages in many ways. Global estimates for annually required adaptation funding vary from some tens of billions USD to over 100 billion USD ${ }^{1}$ and only a limited amount of pledged adaptation funds have been disbursed and have actually provided adaptation benefits on the ground. The adaptation finance landscape remains rather scattered (including finance instruments under the United Nations Framework Convention on Climate Change (UNFCCC), multilateral channels, bilateral ones as well as various channels delivering private funds with adaptation objectives) and systematic collection of lessons learned from climate adaptation is only being initiated. The recent UNFCCC Conferences of the Parties (COPs) have given some hope of advancement with regards to improved coordination and transparency in climate funding (including some progress concerning the Green Climate Fund) but many challenges still remain in operationalizing and monitoring progress.

Simultaneously, an increasing number of initiatives, programmes and projects are being developed and implemented, which either intentionally or unintentionally contribute to both mitigation and adaptation. In some cases these initiatives also contribute to other ("non-climate change") cobenefits such as reduced pollution and health benefits, job creation and poverty alleviation, preservation of natural resources etc. Making a clear distinction between mitigation and adaptation has remained a political and practical necessity within the framework of the international climate negations, and in particular in ensuring that funding ${ }^{2}$ commitments are respected and measures implemented. However, the importance of looking for synergies between adaptation and mitigation is increasingly being understood by practitioners on the ground, development organisations, nongovernmental organizations (NGOs), funding agencies and policy makers.

The launch of initiatives such as the Climate and Development Knowledge Network (CDKN) ${ }^{3}$ focusing on climate compatible development (CCD), and a multitude of new climate mainstreaming approaches and tools ${ }^{4}$ (providing guidance for simultaneously taking into consideration both mitigation and adaptation aspects as part of broader development and poverty reduction objectives) exemplifies this trend. Among developing countries, and in particular the Least Developed Countries (LDCs), the recent Ethiopian development strategy can also be seen as an encouraging indication of this trend - understanding the trade-offs as well as the importance of actively seeking synergies between mitigation and adaptation. Launched in early 2011 under the leadership of the Prime

\footnotetext{
${ }^{1}$ See e.g. World Bank 2010, Dara and the Climate Vulnerable Forum 2012

${ }^{2}$ Taking note of the challenges related to defining and verifying additionality, be it in line e.g. with CDM-type methodologies or related to the overall additionality question of adaptation funding related to ODA.

${ }^{3}$ See CDKN website http://cdkn.org/?loclang=en_gb

${ }^{4}$ See e.g. Finn Church Aid http://www.kua.fi/en/where_we_work/advocacy_work/climate_change_in_our_work/?id=2151
} 
Minister's Office, the Environmental Protection Authority, and the Ethiopian Development Research Institute, The Climate-Resilient Green Economy (CRGE) initiative sets a target of having a national economy which is both climate resilient and carbon neutral by $2025 .^{5}$

Taking into account the already experienced impacts of increasing climate variability and accelerating climate change, as well as the current international financial constraints, the increasing challenges to meet the estimated adaptation funding needs will push all stakeholders to more actively indentify and harness any synergies between adaptation and mitigation activities.

\subsection{Objectives and scope}

During the past years, Nordic countries have been developing and promoting approaches and tools for climate proofing and screening in various areas of development cooperation. These measures primarily aim to strengthen the adaptive capacity of developing countries, in many cases being the most vulnerable to climate change and variability. Also they serve to proof development initiatives against climate risks and hereby improve their potential to successfully contribute to their poverty reduction objectives.

While important work still remains to be done in order to systematically and concretely integrate climate considerations into all planning, management and funding decisions, the Nordic countries are well positioned to act as forerunners in identifying and harnessing any synergies in mitigation and adaptation.

This scoping study can serve the Nordic countries to proactively look for and promote any potential synergies in this area. The Nordic Working Group for Global Climate Negotiations (NOAK) under the Nordic Council of Ministers (NCM) is responsible for the study, funded by the Nordic Council of Ministers.

This scoping study looks at different ways to improve adaptation and mitigation synergies in climate change financing. It reviews existing definitions of synergies and identifies various types of synergies that have been recognized to date. The study looks for existing funding streams for synergetic adaptation and mitigation and explores opportunities to improve financing of activities that provide demonstrable synergies (or avoided trade-offs) between adaptation and mitigation. The focus of the study is in developing countries. While climate policy cannot be separated from development challenges and other policies in a development context, taking note of the nature of this scoping study, the literature review focuses on the synergies and/or trade-offs between climate change mitigation and adaptation. However, the importance of understanding the interconnections and links of these synergies within a broader development context will also be noted in the report.

\footnotetext{
${ }^{5}$ Obviously adaptation and mitigation are here seen as integral parts/sides of one coin, but no longer being the main objectives as such. Their synergies are being recognized and should be contributing to green (including low-carbon) growth, which is simultaneously climate resilient. In order to realize the target, the Government is in the process of putting in place a number of institutional building blocks, including i) a national strategy (CRGE Strategy) that will identify investment priorities, both for adaptation and mitigation, ii) a multi-donor trust fund (CRGE Facility) which will pool and administer climate finance, and iii) detailed plans (including investment plans) for different levels for concretely implementing the climate change strategy. In summer 2012, the components addressing the Green Economy part of CRGE is well advanced and by the end of 2012 the plans for the Climate Resilient part of CRGE should be ready.
} 
Hereby the scoping study provides a foundation for further political deliberation whether it would be interesting to launch further work in this area, e.g. to initiate a more detailed Nordic feasibility study or a pilot project/programme in this area.

\subsection{Approach and reporting}

In line with the spirit of the assignment, the scoping study has been conducted primarily as a literature review. The literature review has served as basis for expert analysis by the international project team. The Gaia team for this assignment has been carefully selected, with advanced skills and experience in the complementary fields of climate mitigation, adaptation and climate finance (Annex 2: Presentation of project team).

The literature review and analysis have been complemented by carefully selected interviews with leading international experts in climate change, adaptation, mitigation, climate finance and development cooperation (Annex 1. List of people consulted). The interviews have served to cover information gaps, to reflect on and validate the expert team's analysis findings and recommendations.

The work has been carried out in September-December 2012 in close cooperation with representatives from the Nordic Working Group for Global Climate Negotiations (NOAK) to ensure that the focus and recommendations serve NOAK in its further deliberations.

Following this introductory section, Section 2 presents a literature review of how synergies between adaptation and mitigation are being defined. It summarizes key types of synergies that have been identified and highlights sectors where various types of synergies have been primarily noted. Also, the literature review describes some key trade-offs between adaptation and mitigation.

Section 3 presents an analysis of opportunities to improve financing on adaptation and mitigation synergies. The analysis provides a preliminary assessment of the potential for concrete activities with simultaneous mitigation and adaptation benefits, identifying regions and sectors of particular interest. Synergies are highlighted based on a review of the climate finance landscape, key challenges and barriers as well as opportunities for funding climate mitigation and adaptation.

The findings and recommendations are presented in section 4. Additional information is provided in Annexes. 


\section{Adaptation and mitigation synergies}

\subsection{Background to climate policy - the balance between mitigation and adaptation}

The problem of climate change has gone through several phases over the last two decades. The initial framing of the problem was to ascribe it to the emissions of greenhouse gases leading to higher concentrations in the atmosphere which in turn will lead to higher atmospheric temperatures and other changes in the climate system over the next decades. Thus the solution to the problem was framed as reducing the emission of greenhouse gases or mitigation. It was also recognized as being a global problem requiring collective actions from all countries and so the United Nations Framework Convention on Climate Change (UNFCCC) was negotiated and signed in June 1992 in Rio at the Earth Summit and came into force a few years later once sufficient countries had ratified it. The UNFCCC provided a global treaty for all countries to take actions to reduce their emission of greenhouse gases but with "common but differentiated responsibilities and respective capabilities". This meant that while all countries pledged to take action, the rich countries, or Annex 1 Parties, needed to take earlier and stronger action to reduce their emission of greenhouse gases.

At the third Conference of the Parties (COP-3) of the UNFCCC, the Kyoto Protocol was signed where the Annex 1 countries agreed to take on targets for emissions reduction by 2012 compared to their 1990 emission levels. The Kyoto Protocol came into force in 2005 when sufficient countries had ratified it. It was, however almost entirely about reducing emissions, or in other words, mitigation ${ }^{6}$.

It was only after the third assessment report of the Intergovernmental Panel on Climate Change (IPCC) came out in 2001 that showed that despite pledges to reduce emission of greenhouse gases, they were continuing to increase. It also highlighted that now a certain amount of climate change was becoming inevitable and unavoidable in the near to medium term of the next one, two and possibly three decades. While mitigation was still important to avoid long-term (over 5-10 decades) catastrophic levels of climate change, it is necessary to also carry out adaptation to the unavoidable impacts of climate change which had become "locked-in" already due to past and current emission of greenhouse gases. The IPCC's Third Assessment Report also stated that while all countries and communities would be affected by climate change eventually, the poorest countries and communities would be the first to be affected. This conclusion made a link with the development agenda for countries, agencies and actors who were involved in poverty alleviation in the poor developing countries. Finally, the Fourth Assessment Report of the IPCC continued the discussion in a chapter on the linkages between adaptation and mitigation defining also what is meant by synergies. The Fifth Assessment Report currently under preparation and due for publication in 2014, will have four separate chapters on adaptation in Working Group II and will also have adaptation and mitigation

\footnotetext{
${ }^{6}$ However, it should be mentioned that Article 12.8 of the Kyoto Protocol does require that a share of the proceeds from CDM activities is directed to finance adaptation: in practice this corresponds to a $2 \%$ share of the value generated by Certified Emissions Reductions (CERs) going to the Adaptation Fund
} 
embedded in many of the sectoral and regional chapters. Some of the key milestones of climate change policy are presented in Figure 1.

Since then, many more development actors have engaged with the climate change issue from the perspective of adaptation to climate change. This has expanded the issue of adaptation to many more actors than were involved with mitigation. For a long time, mitigation actors and activities ran in parallel with adaptation and there was little or no effort to find synergies between the two. That is now beginning to change as linkages between the two are becoming more apparent. The climate finance landscape has seen a similar evolvement, with a strong focus on mitigation, adaptation entering the scene timidly during the past years, and synergetic aspects remaining at an embryonic stage (see Chapter 3).

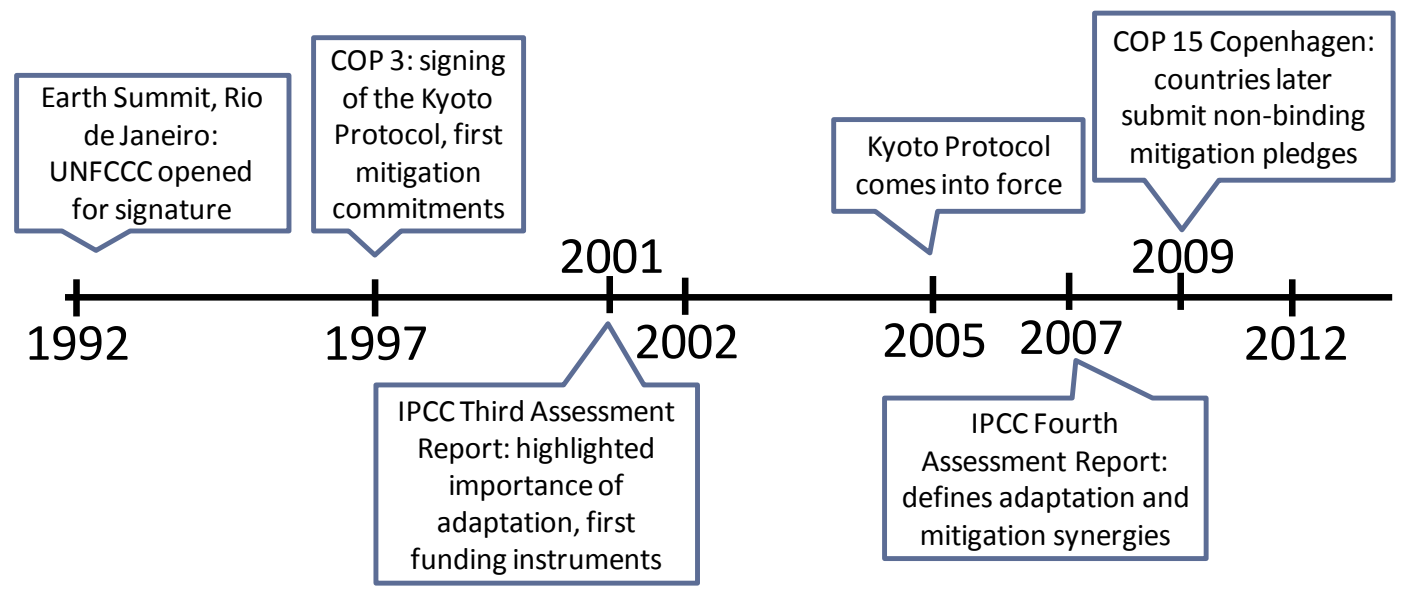

Figure 1. Some key milestones in climate change policy

\subsection{Defining adaptation and mitigation synergies}

\subsubsection{Defining adaptation and mitigation}

In order to critically and fruitfully analyze the potential synergies between adaptation and mitigation, it is important to clearly understand the definitions and contents of mitigation and adaptation. Both are strategies to manage climate change risks, yet there are some key differences between the two approaches that have been studied extensively and well documented in previous research. While this is not the primary focus of this paper, understanding the background and underlying features of adaptation and mitigation is essential to understanding synergies.

Mitigation is defined as an anthropogenic intervention to reduce the sources or enhance the sinks of greenhouse gases ${ }^{7}$. As introduced in the previous chapter, this strategy has also been the primary focus of climate policy in the past ${ }^{8}$. Historically mitigation has also been the primary strategy adopt-

\footnotetext{
${ }^{7}$ IPCC 2001

${ }^{8}$ E.g. Dang, Michaelowa and Tuan 2003, Klein, Schipper and Dessai 2003, Ayers and Huq 2008. The UNFCCC and Kyoto Protocol have committed signatories to stabilizing greenhouse gas emissions at 1990 levels by the year 2000 and to reducing overall emissions by at least $5 \%$ compared to 1990 by the period 2008-2012 (Klein, Schipper and Dessai 2003).
} 
ed by developed countries with lower vulnerability to the impacts of climate change. Developed countries are responsible for the lion's share of emissions increases measured to date, and are therefore seen as having more responsibility for climate change ${ }^{9}$. Mitigation is also referred to as being a more equitable strategy ${ }^{10}$ : those with high emissions take responsibility for reducing emissions. This is also one of the reasons why the overall picture is changing - several developing countries have globally become major emitters of greenhouse gases (GHG) with emissions levels rapidly increasing (see Figure 4).

The impacts of mitigation activities can often be measured in tonnes of carbon equivalent emissions reduced $^{11}$. This allows relatively easy comparison of different mitigation options which can be useful in decision-making. If the implementation costs of mitigation activities are also known, the costeffectiveness of different activities can be calculated and compared ${ }^{12}$. However, the climate benefits of mitigation activities often take time to observe due to the long residence time of greenhouse gases in the atmosphere ${ }^{13}$. Obviously some major co-benefits may accrue in the short-term, such as health benefits from reduced air pollutants. Benefits are generally considered to be global in nature ${ }^{14}$ meaning that a reduction of emissions in one part of the world will benefit all continents. Mitigation has often been a popular strategy in sectors where energy consumption is dominant and/or where impacts on carbon sinks are considerable when looking at environmental impacts. These include, for example, energy, transportation, construction and manufacturing, forestry, waste management and increasingly agriculture ${ }^{15}$. These sectors are generally well organized actors that are used to taking longer term decisions on planning and investments ${ }^{16}$. However, during the $21^{\text {st }}$ century all GHG emitting activities have to be addressed in one way or another in all sectors, taking note that on a global level negative emissions may be a necessity in the long-term to stay within the $2^{\circ} \mathrm{Climit}^{17}$.

Adaptation is defined as adjustment in natural or human systems in response to actual or expected climatic stimuli or their effects, which moderates harm or exploits beneficial opportunities ${ }^{18}$. Adaptation has often been a strategy preferred by developing countries that are more vulnerable to climate change impacts and have lower mitigative capacity given their low level of emissions compared with developed countries ${ }^{19}$. Contrary to mitigation, the impacts of adaptation activities are more difficult to compare. This is not only due to a lack of suitable impact measurement methodolo-

\footnotetext{
${ }^{9}$ Ayers and Huq 2008

${ }^{10}$ Willbanks and Sathaye 2007

${ }^{11}$ While the focus of this study highlights climate change impacts of mitigation, it should be noted, that mitigation can also benefit reductions in air pollutants and energy security, which is a key issue in developing countries

12 Klein, Schipper and Dessai 2003

${ }^{13}$ Klein, Schipper and Dessai 2003

${ }^{14}$ Willbanks et al. 2003, Moser 2011

${ }^{15}$ Locatelli et al. 2011, Swart 2008, Klein, Schipper and Dessai 2003

${ }^{16}$ Klein, Schipper and Dessai 2003

${ }^{17}$ UNEP 2011

${ }^{18}$ IPCC 2001

${ }^{19}$ Ayers and Huq 2008
} 
gy, but also because impacts occur at more local levels ${ }^{20}$ and these may differ significantly depending on the stakeholders involved and/or context. This makes adaptation in some ways more complex than mitigation because its efficacy depends on the local conditions and situations in which adaptation is implemented ${ }^{21}$. The effects of adaptation are commonly observed immediately reducing the vulnerability of those that are able to adapt ${ }^{22}$. Overall, adaptation as a strategy is relevant to a wide spectrum of sectors such as agriculture, tourism and recreation, human health, water management, coastal management, urban planning and nature conservation, to name a few ${ }^{23}$.

For the purposes of this study, the differences between the two strategies as explained above are of course a simplification. The aim is simply to highlight areas where the two strategies differ to help understand the potential challenges and/or opportunities in harnessing any synergies. As the case often is though, there are many exceptions to the traits highlighted in the definitions. For example, adaptation activities may have more global consequences (e.g. adaptation of temperate farmers). Benefits of mitigation activities can be realized already in the short-term, for example, reduced air pollution and the associated health benefits ${ }^{24}$. Increasingly, both adaptation and mitigation are relevant for developed and developing countries.

While there is abundant research highlighting the differences between the two risk management strategies, similarities also exist ${ }^{25}$. Moreover studies are increasingly beginning to view the two as complementary to each other. It is now often cited, that the two are intrinsically linked through their "cause and effect" relationship: the more effective mitigation is now, the less the need for adaptation in the future ${ }^{26}$. There is also a clear link between costs whereby the more mitigation activities undertaken the higher their cost, but the less need to engage in adaptation activities in the future and invest in adaptation ${ }^{27}$. In any case, a mix of mitigation and adaptation measures are needed as existing emissions have already locked our planet to a certain level of climate change. The internationally pledged GHG reduction commitments ${ }^{28}$ are not sufficient to keep temperature increases below the two degree level ${ }^{29}$, considered a level of dangerous climate change.

While these linkages have already gained some attention ${ }^{30}$, the publication of the IPCC's Fourth Assessment Report included a discussion of the inter-relationships of adaptation and mitigation that seems to have raised the profile of the relationship between the two strategies. A popular view

\footnotetext{
${ }^{20}$ Willbanks et al. 2003, Moser 2011

${ }^{21}$ Willbanks 2007

${ }^{22}$ E.g. Klein 2007a, Locatelli et al. 2011, Ayers and Huq 2008

${ }^{23}$ Klein, Schipper and Dessai 2003, Swart 2008

${ }^{24}$ Swart and Raes 2007. Co-benefits refers to benefits that extend beyond climate-related benefits or direct stakeholders, could also be described as secondary or ancillary benefits

${ }^{25}$ Swart and Raes 2007

${ }^{26}$ E.g. Dang, Michaelowa and Tuan 2003, Ayers and Huq 2008, Swart and Raes 2007

${ }^{27}$ Holdridge 1947, 1967 and M.L. Perry in Klein et al. 2007b

${ }^{28}$ UNEP 2011

${ }^{29}$ The vast majority of scientists now agree that if global warming exceeds a mean temperature of $2{ }^{\circ} \mathrm{C}$ it will lead to dangerous, irreversible and practically uncontrollable consequences for both nature and mankind. An increasing number of countries have made it their official target to limit the rise of the global mean temperature to $2^{\circ} \mathrm{C}$ or less as a guard rail for their endeavours in climate policy.

${ }^{30}$ E.g. Dang, Michaelowa and Tuan 2003 and Klein, Schipper and Dessai 2003
} 
seems to be forming that looking at the two strategies together can offer attractive opportunities not only for better management of climate change risks and reducing vulnerability, but for sustainable development in a broader context ${ }^{31}$. An integrated approach is argued to help achieve the United Nations' Millennium Development Goals in the long term ${ }^{32}$, to help bridge the gap between adaptation priorities in developing countries and mitigation in industrialized countries ${ }^{33}$, and to result in more responsive, comprehensive and efficient climate policy ${ }^{34}$.

\subsubsection{Existing definitions of synergies between adaptation and mitigation}

Synergies between adaptation and mitigation, as defined in IPCC's Fourth Assessment Report, refers to the "interaction of adaptation and mitigation so that their combined effect is greater than the sum of their effects if implemented separately ${ }^{\prime \prime 35}$. This definition is expanded with the distinction of four types of inter-relationships between adaptation and mitigation:
a. Adaptation actions that have consequences for mitigation,
b. Mitigation actions that have consequences for adaptation,
c. Decisions that include trade-offs or synergies between adaptation and mitigation,
d. Processes that have consequences for both adaptation and mitigation. ${ }^{36}$

This IPCC definition provides a broad framework for looking at the potential synergies and/or tradeoffs $^{37}$ between adaptation and mitigation.

Overall (as the literature review will reveal) there has been a tendency to look at synergies through the consequences or impacts of adaptation and mitigation actions. The origin of the word synergy in Latin synergia or Greek synergos translates into working together ${ }^{38}$, implying that there may be value in looking at synergies in similar processes and/or shared stakeholders. Some of the available literature highlights the similarities in processes and capacities ("behind" adaptation and mitigation measures) as key areas where synergies could be identified and harnessed. ${ }^{39}$

The climate change research community, development organisations, policy makers, NGOs and practitioners on the ground use a wide range of terminology to describe synergies: links between ${ }^{40}$,

\footnotetext{
${ }^{31}$ E.g. Willbanks and Sathaye 2007, Ayers and Huq 2008, Swart 2008

${ }^{32}$ Swart 2008

${ }^{33}$ Ayers and Huq 2008

${ }^{34}$ Dang, Michaelowa and Tuan 2003

${ }^{35}$ Klein et al. 2007b

${ }^{36}$ Klein et al. 2007b

${ }^{37}$ Trade-offs are defined as: "a balancing of adaptation and mitigation when it is not possible to carry out both activities fully at the same time (e.g. due to financial or other constraints) (Klein et al. 2007b)

${ }^{38}$ Merriam Webster Online Dictionary http://www.merriam-webster.com/dictionary/synergy

${ }^{39}$ See e.g. Klein, Schipper and Dessai 2003, pointing out that adaptive and mitigative capacity have considerable similarities and are often determined by the same set of factors, such as economic wealth, technology and infrastructure, information, knowledge and skills, institutions, equity and social capital.

${ }^{40}$ Verchot et al. 2007, Dang, Michaelowa and Tuan 2003, Locatelli et al. 2011
} 
complementarity of ${ }^{41}$, integration of ${ }^{42}$ and interaction between ${ }^{43}$ adaptation and mitigation. In many cases, synergies are examined in a broader sustainable development context and reference is often made to developing adaptive and mitigative or even response capacity ${ }^{44}$, climate compatible development ${ }^{45}$, reducing vulnerabilities, seeking co-benefits with development policy and enabling sustainable livelihoods. While climate change policy cannot be separated from development challenges and other policies in a development context, taking note of the nature of this scoping study, the literature review here focuses primarily on the synergies and/or trade-offs between climate change mitigation and adaptation. The importance of understanding the interconnections within a broader development context will be highlighted in Chapter 4 of this report.

\subsection{Types of synergies between adaptation and mitigation}

As already mentioned in the definitions, sectors have historically been more inclined to adopt either a mitigation or adaptation strategy; however, this does not mean that opportunities for the other strategy do not exist, and thus, opportunities for synergies. Sectors that have often been recognized as having more potential for synergies include: agriculture, forestry, construction and urban infrastructure, water resource management and land-use ${ }^{46}$.

In agriculture, Rosenzweig and Tubiello (2007) have studied both mitigation and adaptation opportunities and identified some possible synergies. They argue that finding synergies in this sector is imperative because climate change stresses and socio-economic pressures, such as increasing demand/competition for food, fibre and fuel, require robust options that can deal with both climate and societal challenges. One concrete example of synergies is where fallow systems are transformed to continuously cultivated areas (to maximise production under heavier precipitation conditions) increasing the ability of soils to sequester carbon. A similar synergy is relevant where increased irrigation and fertilizer use needed to maintain production would enhance sequestration potential. ${ }^{47}$ In the latter example, however, some argue that increasing irrigation requires more energy and unless this can be produced from non-fossil sources, emissions would increase ${ }^{48}$. This same outcome would apply in the case of increasing wastewater reuse, where wastewater needs to be treated and this again requires increasing energy inputs. Yet the potential for synergies in agriculture is supported by the argument that current mitigation techniques were originally designed as being management strategies that enhance stability and resilience of cropping systems against climate variability,

\footnotetext{
${ }^{41}$ Mata and Budhooram 2007

${ }^{42}$ Willbanks and Sathaye 2007, Dang, Michaelowa and Tuan 2003, Muys, Akinnifesi and Verbist [no date], Klein, Schipper and Dessai 2003, Willbanks et al. 2003, Swart and Raes 2008, Ayers and Huq 2008

${ }^{43}$ Rosenzweig and Tubiello 2007

${ }^{44}$ Klein et al. 2007b, Swart and Raes 2007

${ }^{45}$ E.g. 2010 founded CDKN (The Climate and Development Knowledge Network) supports decision-makers in designing and delivering climate compatible development, with a particular aim to understand and promote the synergies between adaptation, mitigation and sustainable poverty reduction ( $\underline{\mathrm{http}} / / / \mathrm{cdkn} . \mathrm{org} /$ ?loclang=en gb )

${ }^{46}$ Klein 2007a, Swart and Raes 2007, Swart 2008

${ }^{47}$ Rosenzweig and Tubiello 2007

${ }^{48}$ Klein et al. $2007 \mathrm{~b}$
} 
thus, making them adaptive strategies. ${ }^{49}$ Many mitigation options that involve soil carbon sequestration have synergies with adaptation as they can result in better plant nutrient content and increased water retention capacity leading to higher yields and greater resilience ${ }^{50}$.

As of January 2012, EPIC (Economics \& Policy Innovations for Climate-Smart agriculture), under the FAO's Agricultural and Development Economics Division, has initiated a project on climate-smart agriculture with three partner countries-Malawi, Vietnam and Zambia. The objective is to "enhance the capacity of agricultural systems to support food security, incorporating the need for adaptation and the potential for mitigation into sustainable agriculture development strategies". As part of this work, synergies and trade-offs between adaptation and mitigation will be looked at. ${ }^{51}$

Many opportunities can be identified from the forestry and land use sectors. One concrete example of synergies deals with using drought-resistant varieties of tree species in planted forests to improve tree species' resilience to water stress while increasing potential for carbon sequestration ${ }^{52}$. Another much quoted example is the building of mangrove plantations that protect coastal areas from storms and simultaneously sequester carbon ${ }^{53}$. Afforestation and reforestation can increase carbon sinks and simultaneously decrease water evaporation and lower vulnerability to heat stress ${ }^{54}$. Reforestation can also prevent flooding and erosion while sequestering carbon ${ }^{55}$. Obviously the REDD + (Reduced Emissions from Deforestation and Forest Degradation plus conservation) mechanism could have the potential to systematically harness a number of synergies between mitigation and adaptation (see Chapter 3.2). It should be noted, that the synergies in the examples presented above are not always guaranteed. For example, the types of trees that can prevent flooding may not be the most effective in sequestering carbon emissions ${ }^{56}$. One more example from coastal afforestation comes from Bangladesh, where coastal forests stabilise shorelines and provide protection against storms and other extreme events while simultaneously improving carbon sequestration rates ${ }^{57}$. Improving forest fire management has also been identified as having potential synergies: early warning systems and improved fire fighting ${ }^{58}$ can prevent or at least limit emissions from fires, but also help adapt to increasing climate variability and extreme events causing forest fires such as droughts or storms.

While the energy sector has traditionally focused on mitigation, synergies with adaptation have been increasingly identified in the past years, particularly in developing cleaner and more renewable energy sources for rural areas. Renewable rural electrification, for example, where fossil fuel powered lamps and generators can be replaced with decentralised renewable energy sources, provides

\footnotetext{
${ }^{49}$ Rosenzweig and Tubiello 2007

${ }^{50}$ FAO 2009

${ }^{51}$ EPIC 2012

52 Locatelli et al. 2011

${ }^{53}$ Locatelli et al. 2011, Ayers and Huq 2008

${ }^{54}$ Klein et al. 2007b

${ }^{55}$ Swart and Raes 2007

${ }^{56}$ Dang, Michaelowa and Tuan 2003

${ }^{57}$ Ayers and Huq 2008

${ }^{58}$ Swart and Raes 2007
} 
opportunities for synergies. These types of projects avoid emissions through replacing fossil fuelbased energy generation with renewable energy. At the same time, renewable rural electrification builds adaptive capacity ${ }^{59}$ as access to electricity meets basic needs ${ }^{60}$ and rural areas are less dependent on the functioning of remote electricity networks and possible power shortages. Renewable rural electrification also has potential to provide co-benefits to reducing poverty and improving livelihoods.

Hydropower plays a significant role in reducing fossil fuel-based energy production and limiting vulnerability to precipitation variability ${ }^{61}$. Hydropower also has significant co-benefits, such as improving domestic energy security and stimulating economic development ${ }^{62}$. However, hydropower is a climate sensitive form of renewable energy. It has been argued, that the flooding of reservoirs could cause severe increases in GHG emissions, particularly methane due to vegetation decay ${ }^{63}$, and that these increases do not always compare favourably with fossil fuel-powered plants, particularly in the case of shallow, warm tropical dams ${ }^{64}$. Despite these arguments, hydropower still has considerable mitigation potential.

Another example is the promotion of cleaner, energy-efficient stoves to households and institutions in developing countries. Multiple benefits have been widely reported: for mitigation through reduced GHG emissions due to more efficient burning, reduced deforestation, improved carbon sequestration etc.; for adaptation through reduced deforestation and reduced vulnerability e.g. to landslides, droughts etc.; and also for health through reduced fumes and respiratory problems and overall improved livelihoods. ${ }^{65}$ However, similarly to the hydropower example, there are also tradeoffs that need to be considered in shifting to more climate sensitive renewable energy generation.

There are positive experiences from combining mitigation and adaptation efforts through promoting sustainable charcoal briquettes in Tanzania. Increasing charcoal demand causes severe deforestation and leads to erosion in vulnerable lands. As household energy infrastructure is mostly based on relatively cheap charcoal especially in urban areas, switching to more sustainable energy sources such as electricity or gas has been seen difficult due to their higher costs. However, sustainable charcoal briquettes produced from agricultural waste are economically competitive compared to wood charcoal. Using agricultural waste and other unused biomass residues instead of wood improves reforestation and thus has a positive impact on preventing erosion and improving watershed management. As a renewable raw material, charcoal briquettes are also nearly carbon neutral.

Finally, the production of vegetable oils and biodiesel can provide synergies between adaptation and mitigation. Research has identified several vegetable oil crops that can survive in severe drought

\footnotetext{
${ }^{59}$ Venema and Cisse 2004 in Ayers and Huq 2008

${ }^{60}$ See, for example, Nordic Development Fund project descriptions: Off-grid Electrification Using Wind and Solar Energy in Kenya (http://www.ndf.fi/index.php?id=123) or Sustainable Electrification and Renewable Energy Programme in Nicaragua (http://www.ndf.fi/index.php?id=57)

${ }^{61}$ Swart and Raes 2007

62 Mata and Budhooram 2007

${ }^{63}$ World Commission on Dams 2000

${ }^{64}$ Mata and Budhooram 2007, World Commission on Dams 2000

${ }^{65}$ See Global Alliance for Clean Cookstoves http://www.cleancookstoves.org/
} 
conditions even in the face of a two percent rise in average temperatures. In addition, for example, peanuts, sesame and sunflower also increase the amount nitrogen in the soil providing benefits to other crops and sesame can also protect against insects through the substances it releases. The planting of these types of crops and use in biodiesel production will reduce carbon dioxide, sulphur and particulate matter emissions considerably compared to diesel oil. The selection of vegetable oil crop is essential to enable these synergies and to avoid competition with subsistence crops. ${ }^{66}$

Infrastructure construction and planning have the potential to foster adaptation and mitigation synergies particularly in urban areas. Possible measures could include designing structures by planning sites that are not vulnerable to sea level rise or flooding, that have low transportation requirements (or that are well connected with public transportation) and that apply energy efficient building characteristics ${ }^{67}$. Another example comes from Denmark where the City of Copenhagen has suggested synergies from decreasing impermeable areas in its municipal spatial plan from $2009^{68}$ : this will decrease the need to pump rainwater from the city and therefore decrease energy consumption, whilst providing more natural surfaces helping to reduce vulnerability against floods and increased precipitation.

Another example of synergies comes from the insurance industry, where climate change is relevant for both the property-casualty and life-health segments of the industry. For example, measures that reduce the vulnerability of buildings and humans to urban heat-island effects heat catastrophes include urban forestry and green roofs reducing the reflective power of various surfaces such as roofs and pavements. These measures tend to increase energy efficiency through reducing the need for air conditioning and therefore cutting greenhouse gas emissions. In addition to property insurance, the above example would reduce smog formation due to lower ambient temperatures providing co-benefits also for health insurance. ${ }^{69}$ Many of the other sectors where synergies have been identified are also relevant to the insurance industry, such as property insurance from improved forest fire management or energy efficiency. The role of insurance is especially relevant in the case of extreme events and disasters.

One more example of identified synergies comes from the waste treatment sector. In a project implemented by an NGO named Waste Concern in Bangladesh, organic waste from landfill is diverted to a composting plant in order to produce organic compost. This reduces methane emissions from anaerobic processes at landfill. In addition, the use of organic compost increases moisture retention and fertility of the soil it is added to, reducing vulnerability to drought and increasing carbon sequestration rates. ${ }^{70}$

Table 1 presents a summary of the examples identified to date based on the literature review. The examples described are based on examples found in current research. This does not mean that potential synergies could not be found in other sectors as well. For example, in the transportation sector, the planning of the public transport networks and mode selection could be done in a way

\footnotetext{
${ }^{66}$ La Rovere, Avzaradel and Monteiro 2009

${ }^{67}$ Swart and Raes 2007

${ }^{68}$ Municipality of Copenhagen 2009 in Larsen Kornov and Wejs 2012

${ }^{69}$ Mills 2007

${ }^{70}$ Ayers and Huq 2008
} 
that builds resilience against sea level rise, flooding and extreme weather events. Network planning that sets emissions intensity as a decision-making criterion along with the ability to build resilience against climate change risks has the potential to reduce emissions while reducing the vulnerability of the public transport network. There is no evidence yet that these synergies could be achieved. However, some transport agencies in the Nordic countries have already taken steps to study the life cycle impacts of different transport alternatives providing a sound basis for mitigation efforts ${ }^{71}$ and there are intentions to use these analyses in the planning of the structure and design of transport networks in the future ${ }^{72}$.

\footnotetext{
${ }^{71}$ E.g. Stripple and Uppenberg 2010, Hagstrom et al. 2011, Illman et al. 2012

${ }^{72}$ Personal communication with Swedish, Norwegian and Finnish Transport Agencies, September 2012
} 
Table 1. Synergies identified based on the literature review

\begin{tabular}{|c|c|c|c|c|}
\hline Sector & Measure & Mitigation potential & Adaptation potential & Identified trade-offs \\
\hline \multirow[t]{3}{*}{ Agriculture } & $\begin{array}{l}\text { Fallow systems transformed } \\
\text { to continuously cultivated } \\
\text { areas }\end{array}$ & $\begin{array}{l}\text { Enhanced carbon sequestration } \\
\text { potential of soil }\end{array}$ & $\begin{array}{l}\text { Enabling/maximising production } \\
\text { under heavier precipitation condi- } \\
\text { tions }\end{array}$ & \\
\hline & $\begin{array}{l}\text { Increasing irrigation and } \\
\text { fertilizer use }\end{array}$ & $\begin{array}{l}\text { Enhanced carbon sequestration } \\
\text { potential of soil }\end{array}$ & $\begin{array}{l}\text { Maintaining production under } \\
\text { drought conditions }\end{array}$ & $\begin{array}{l}\text { Increased energy use and emis- } \\
\text { sions (unless produced from non- } \\
\text { fossil sources) }\end{array}$ \\
\hline & $\begin{array}{l}\text { Increasing wastewater } \\
\text { reuse }\end{array}$ & $\begin{array}{l}\text { Reduced emissions from de- } \\
\text { creased energy needed to pump } \\
\text { freshwater }\end{array}$ & $\begin{array}{l}\text { Maintaining production under } \\
\text { drought conditions }\end{array}$ & $\begin{array}{l}\text { Increased energy use (unless } \\
\text { produced from non-fossil } \\
\text { sources) }\end{array}$ \\
\hline \multirow[t]{4}{*}{$\begin{array}{l}\text { Forestry and } \\
\text { land use }\end{array}$} & $\begin{array}{l}\text { Using drought-resistant } \\
\text { varieties of tree species in } \\
\text { planted forests }\end{array}$ & $\begin{array}{l}\text { Enhanced carbon sequestration } \\
\text { potential }\end{array}$ & $\begin{array}{l}\text { Improved tree species' resilience to } \\
\text { water stress }\end{array}$ & $\begin{array}{l}\text { Suitable trees may not be the } \\
\text { most effective in sequestering } \\
\text { carbon }\end{array}$ \\
\hline & $\begin{array}{l}\text { Building of mangrove plan- } \\
\text { tations (or other coastal } \\
\text { afforestation) }\end{array}$ & $\begin{array}{l}\text { Enhanced carbon sequestration } \\
\text { potential }\end{array}$ & $\begin{array}{l}\text { Protection of coastal areas from } \\
\text { storms and flooding, improving } \\
\text { species habitat }\end{array}$ & \\
\hline & $\begin{array}{l}\text { Afforestation and reforesta- } \\
\text { tion }\end{array}$ & $\begin{array}{l}\text { Enhanced carbon sequestration } \\
\text { potential }\end{array}$ & $\begin{array}{l}\text { Higher water retention, decreased } \\
\text { water evaporation and lower vul- } \\
\text { nerability to heat stress, prevention } \\
\text { of flooding, landslides and erosion }\end{array}$ & \\
\hline & $\begin{array}{l}\text { Improving forest fire man- } \\
\text { agement }\end{array}$ & $\begin{array}{l}\text { Prevention or at least limitation } \\
\text { of emissions from forest fires }\end{array}$ & $\begin{array}{l}\text { Increasing adaptive capacity to } \\
\text { increasing climate variability and } \\
\text { extreme events causing forest fires } \\
\text { such as droughts or storms }\end{array}$ & \\
\hline \multirow[t]{2}{*}{ Energy } & $\begin{array}{l}\text { Renewable rural electrifica- } \\
\text { tion }\end{array}$ & $\begin{array}{l}\text { Reduced emissions from avoid- } \\
\text { ance of fossil fuel-based energy }\end{array}$ & $\begin{array}{l}\text { Improved adaptive capacity } \\
\text { through access to electricity, reduc- } \\
\text { ing dependence on centralised } \\
\text { energy production and reduced } \\
\text { vulnerability to disturbances in } \\
\text { transmission }\end{array}$ & $\begin{array}{l}\text { Potential trade-offs through high- } \\
\text { er energy costs for households }\end{array}$ \\
\hline & Hydropower & $\begin{array}{l}\text { Reduced emissions from avoid- } \\
\text { ance of fossil fuel-based energy }\end{array}$ & $\begin{array}{l}\text { Limitation of vulnerability to pre- } \\
\text { cipitation variability and exposure } \\
\text { to floods }\end{array}$ & $\begin{array}{l}\text { Hydropower is a climate sensitive } \\
\text { form of renewable energy. Flood- } \\
\text { ing of reservoirs could also in- } \\
\text { crease GHG emissions }\end{array}$ \\
\hline
\end{tabular}




\begin{tabular}{|c|c|c|c|c|}
\hline Sector & Measure & Mitigation potential & Adaptation potential & Identified trade-offs \\
\hline \multirow[t]{3}{*}{$\begin{array}{l}\text { Energy } \\
\text { (continued) }\end{array}$} & $\begin{array}{l}\text { Planting vegetable oil crops } \\
\text { for biodiesel production }\end{array}$ & $\begin{array}{l}\text { Reduced emissions compared } \\
\text { with traditional diesel oil }\end{array}$ & $\begin{array}{l}\text { Reduced vulnerability due to } \\
\text { drought resistant seeds, more di- } \\
\text { versified agricultural production }\end{array}$ & $\begin{array}{l}\text { Not all vegetable oil crops can be } \\
\text { planted alongside subsistence } \\
\text { crops causing competition over } \\
\text { land use }\end{array}$ \\
\hline & $\begin{array}{l}\text { Biocharcoal from agricul- } \\
\text { tural waste }\end{array}$ & $\begin{array}{l}\text { Reduced emissions from avoid- } \\
\text { ance of fossil fuel-based energy, } \\
\text { improved carbon sequestration } \\
\text { due to avoided deforestation }\end{array}$ & $\begin{array}{l}\text { Erosion prevention and improved } \\
\text { watershed management, reduced } \\
\text { vulnerability to increasing energy } \\
\text { prices }\end{array}$ & \\
\hline & Energy-efficient stoves & $\begin{array}{l}\text { Reduced emissions due to more } \\
\text { efficient burning, improved } \\
\text { carbon sequestration due to } \\
\text { avoided deforestation }\end{array}$ & $\begin{array}{l}\text { Reduced vulnerability to landslides, } \\
\text { droughts and extreme events due } \\
\text { to ecosystem management. More } \\
\text { resilient livelihoods due to health } \\
\text { benefits, time and cost savings in } \\
\text { households }\end{array}$ & \\
\hline \multirow[t]{2}{*}{$\begin{array}{l}\text { Infrastructure } \\
\text { planning and } \\
\text { construction }\end{array}$} & $\begin{array}{l}\text { Considering climate change } \\
\text { in infrastructure design and } \\
\text { planning }\end{array}$ & $\begin{array}{l}\text { Reduced emissions from more } \\
\text { efficient transportation oppor- } \\
\text { tunities and energy efficient } \\
\text { buildings, enhanced carbon } \\
\text { sinks from e.g. green roofs }\end{array}$ & $\begin{array}{l}\text { Reduced vulnerability to e.g. sea } \\
\text { level rise or flooding or heat waves }\end{array}$ & \\
\hline & $\begin{array}{l}\text { Decreasing impermeable } \\
\text { areas }\end{array}$ & $\begin{array}{l}\text { Reduced emissions from de- } \\
\text { creased need to pump rainwa- } \\
\text { ter and decreased energy con- } \\
\text { sumption }\end{array}$ & $\begin{array}{l}\text { Reduced vulnerability to sea level } \\
\text { rise or flooding }\end{array}$ & \\
\hline Insurance & $\begin{array}{l}\text { Encouraging urban forestry } \\
\text { to reduce urban heat island } \\
\text { effect through property } \\
\text { /health insurance }\end{array}$ & $\begin{array}{l}\text { Reduced emissions from energy } \\
\text { efficiency }\end{array}$ & $\begin{array}{l}\text { Reduced vulnerability to extreme } \\
\text { weather such as heat waves or } \\
\text { flooding, reduced health impacts } \\
\text { from avoided smog formation }\end{array}$ & \\
\hline $\begin{array}{l}\text { Waste } \\
\text { treatment }\end{array}$ & $\begin{array}{l}\text { Organic waste is diverted } \\
\text { from landfill to a compost- } \\
\text { ing plant in order to pro- } \\
\text { duce organic compost }\end{array}$ & $\begin{array}{l}\text { Reduced emissions from avoid- } \\
\text { ed landfill, increased carbon } \\
\text { sequestration }\end{array}$ & $\begin{array}{l}\text { Increased moisture retention and } \\
\text { fertility reducing vulnerability to } \\
\text { drought }\end{array}$ & \\
\hline
\end{tabular}


Synergies between adaptation and mitigation have also intrigued policy makers and planners dealing with broader development approaches. Concepts such as "climate compatible development", "climate resilient development", "green growth" and "low carbon development" have emerged in the past few years. These approaches underline the close linkages between responses to climate change and responses to other development challenges, such as achieving the Millennium Development Goals. For example, the Climate and Development Knowledge Network calls for an approach that "moves beyond the traditional separation of adaptation, mitigation and development strategies"73. Figure 3 summarises how these are all interlinked. These concepts are fairly new and there is little evidence yet of whether these as development approaches are able to harness synergies between adaptation and mitigation.

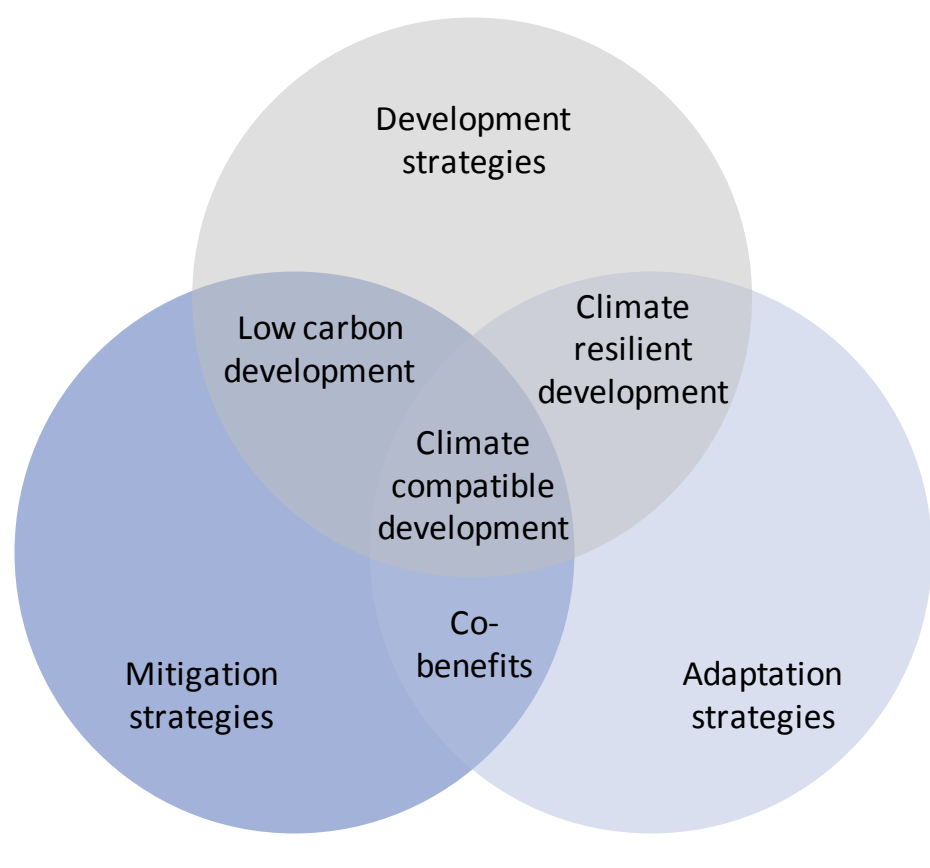

Figure 3. Climate compatible development ${ }^{74}$

Although the synergies mentioned in this scoping study present exciting opportunities to address mitigation and adaptation simultaneously, it should be mentioned, that purposefully seeking synergies is not automatically an effective way to address management of climate change risks. This could lead to overly complex projects that are not cost-effective and that do not result in sufficient mitigation and adaptation benefits ${ }^{75}$. More research is needed to demonstrate and validate the existence of synergies and their added value. In the following chapter, this study seeks to evaluate the potential of synergies by looking at geographical and sectoral factors that can either hinder or enhance synergies.

\footnotetext{
${ }^{73}$ Mitchell and Maxwell 2010

74 adapted from Zadek 2009, and informal communication with staff from the UK Department for International Development, in Mitchell and Maxwell 2010

${ }^{75}$ Klein, Schipper and Dessai 2003
} 


\section{Opportunities to improve financing on adapta- tion and mitigation synergies}

\subsection{Assessing the importance and size of the synergies - next steps}

While the concept of synergies between mitigation and adaptation has been increasingly discussed during the past decade, the amount of research into the subject and the resulting evidence base remains rather scattered. The literature review (see Chapter 2) presented a number of interesting cases from various sectors and countries. Overall, it can be concluded that synergies can be found in a relatively wide array of sectors but examples are few and no systematic analysis of the global potential or sizes or types of optimal synergetic projects per sector has been conducted. The types and sizes of synergies/trade-offs have been looked upon (if at all) mainly in a qualitative manner in selected sectors.

There are various ways to approach the analysis of the types and sizes of potential synergies/tradeoffs and a few of these approaches are suggested below. These have been identified as potential starting points for analyzing and increasing understanding on the potential of synergies in different regions, countries and sectors.

\subsubsection{Developing countries with major mitigation potential and with major vulnerabilities}

Evidently developing countries with major emissions, and in most cases rapidly increasing emissions, are of particular interest when looking for potential synergies and trade-offs from the perspective of required mitigation measures. While within the climate negotiations framework no legal commitments for developing countries have been agreed upon, several developing countries have outlined national strategies for energy efficiency, promotion of renewable energy sources, reduced deforestation programs, introduction of market mechanisms etc. with the aim to contribute to emissions reductions, echoing the principle of "common but differentiated responsibilities" (the cornerstone of the UNFCCC). After the Copenhagen accord many developing countries have prepared Nationally Appropriate Mitigation Actions and several of these include plans that have since prospered with the support of international aid $^{76}$.

When looking at statistics on national carbon dioxide emissions, it is clear to see that the top positions are increasingly occupied by fast growing economies and developing countries (see Figure 4). These include the BRIC-countries (Brazil, Russia, India and China) but also, for example, countries such as South Africa, Indonesia and Taiwan. Not only are their absolute emissions high, but the growth rate of their emissions is alarming. Emissions for China and India in 2011 alone increased $9 \%$ and $6 \%$ respectively and growth rates between 2002 and 2008 were $150 \%$ and $75 \%$ respectively. ${ }^{77}$. Expectations are that the primary energy consumption of BRIC-countries will grow by $72 \%$ between

\footnotetext{
${ }^{76}$ See http://unfccc.int/meetings/cop 15/copenhagen accord/items/5265.php

${ }^{77}$ Olivier, Janssens-Maenhout and Peters 2012
} 
2005 and 2030 (compared with $29 \%$ in the 30 OECD countries) ${ }^{78}$. BRIC-countries are facing increasing pressures in international climate change negotiations to commit to emissions reduction targets and mitigation actions.

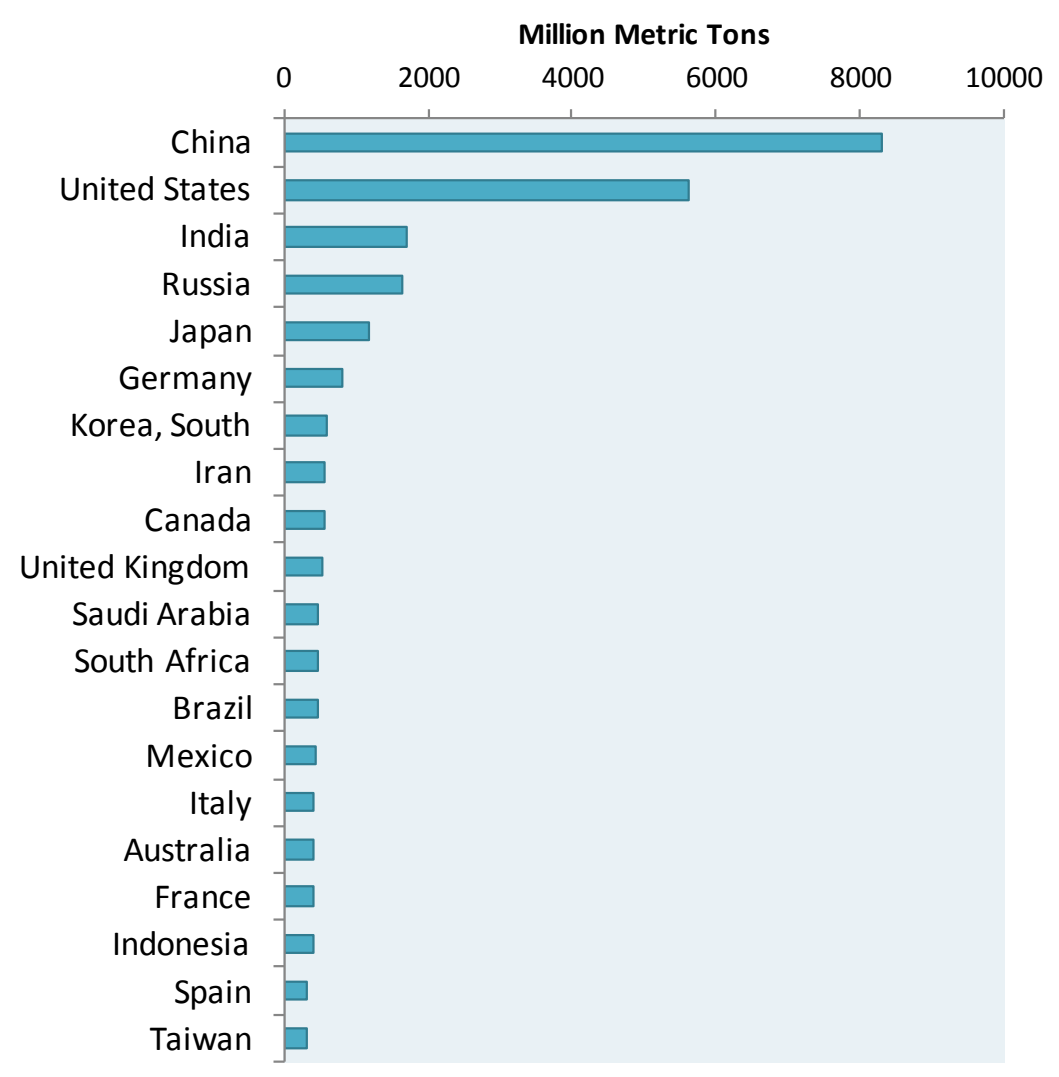

Figure 4. Top 20 Carbon Dioxide Emitters (2010) ${ }^{79}$

The other critical dimension in trying to understand the priority regions when looking for potential adaptation and mitigation synergies is looking at the vulnerability of developing countries. Various indicators and listings have been produced to describe the level of vulnerability of countries. Figure 5 shows the countries of the world coloured according to the level of severity of the climate risks they face over the next 30 years ${ }^{80}$. The countries featuring the highest risk category include Bangladesh, India, Philippines, Vietnam, Nepal, Ethiopia and Thailand, to name a few. Another mapping published in the $2^{\text {nd }}$ edition of the Climate Vulnerability Monitor provides similar results (see Figure 6$)^{81}$.

\footnotetext{
${ }^{78}$ OECD 2008

${ }^{79}$ U.S. Energy Information Administration 2010. Note, this statistic includes only CO2-emissions from the consumption of energy and does not take into account land use and land use changes or forestry. More up-to-date and comprehensive information may be available from the World Resources Institute's Climate Analysis Indicators Tool, however, at the time of writing this report, the database was being reconstructed and data was not available.

${ }^{80}$ Maplecroft, map available for registered users at: http://maplecroft.com/about/news/ccvi.html

${ }^{81}$ Dara and the Climate Vulnerable Forum 2012
} 


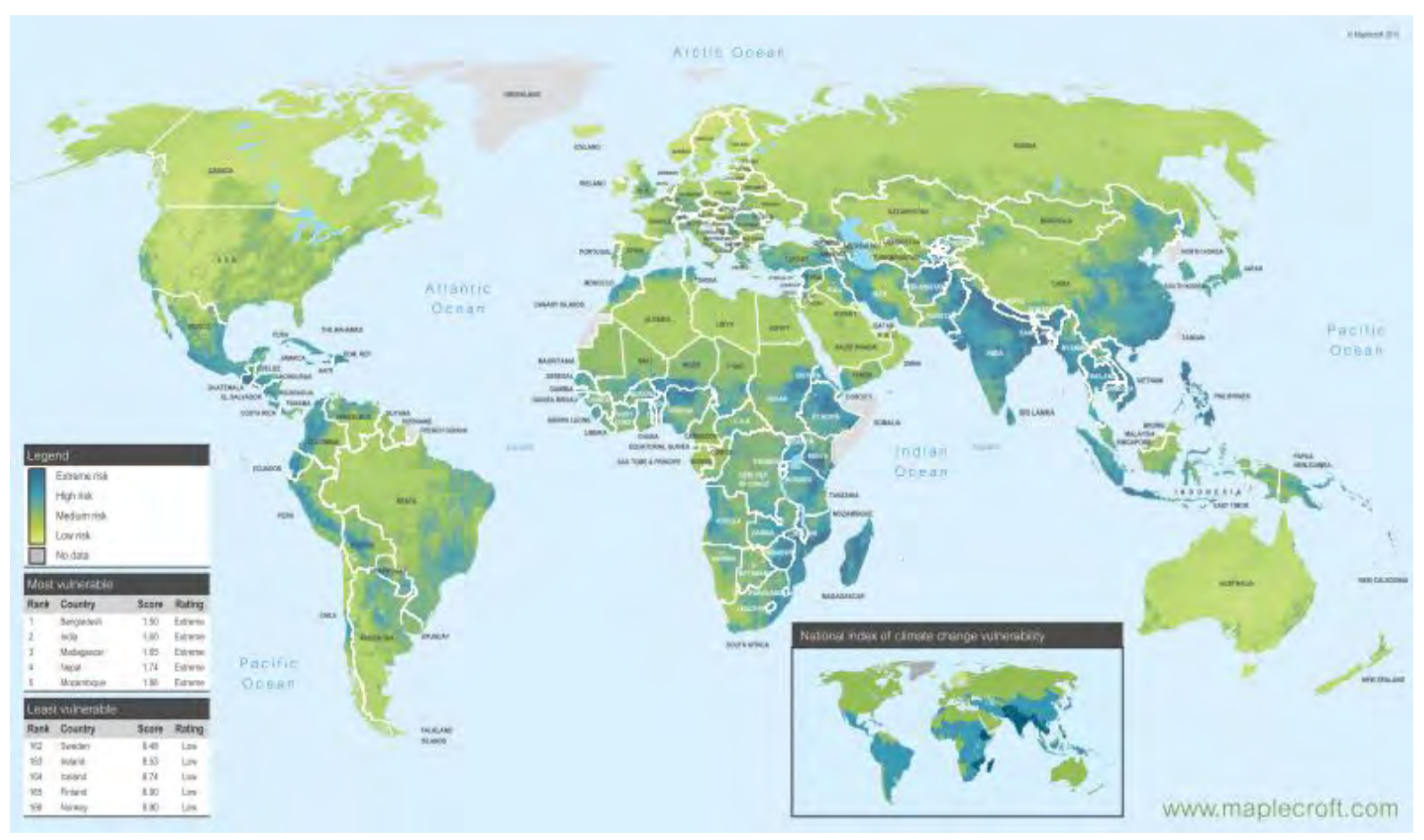

Figure 5. Climate Change Vulnerability Map $2011^{82}$

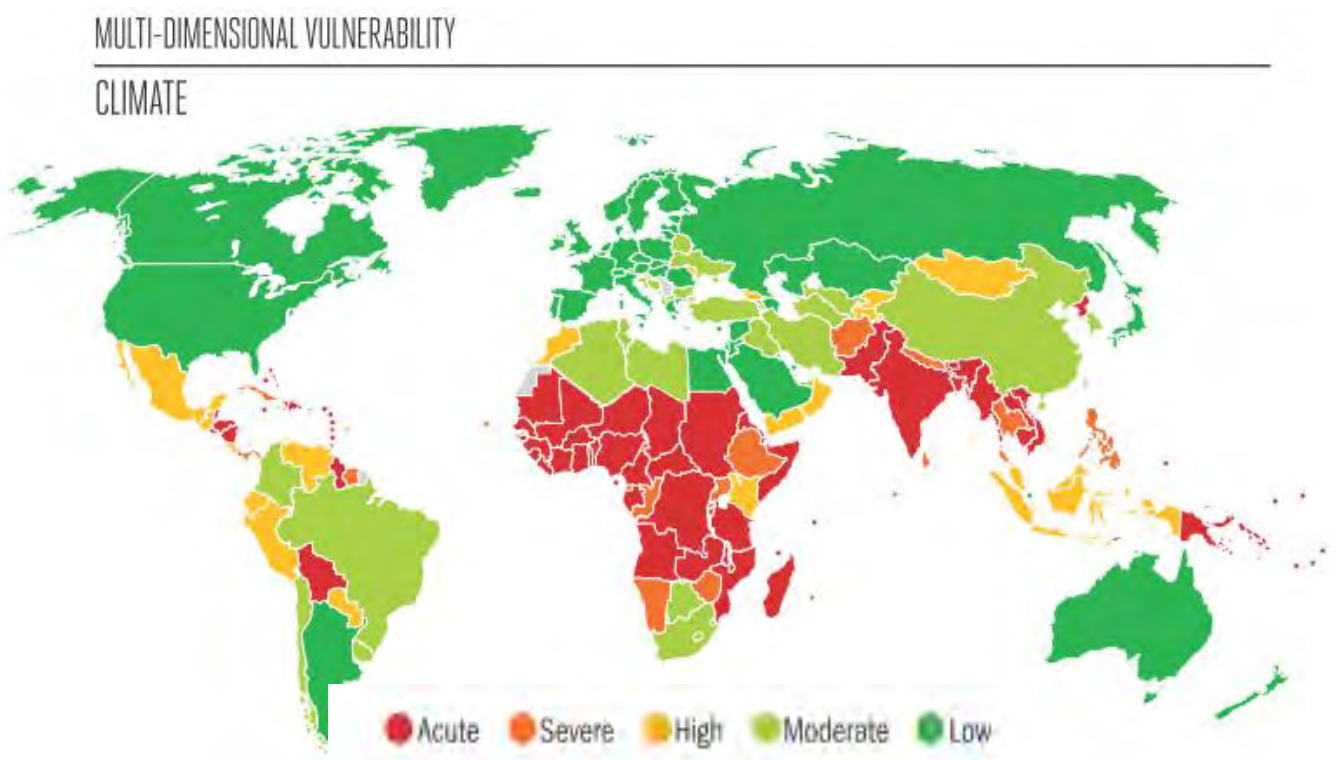

Figure 6. Climate vulnerability map $^{83}$

\footnotetext{
${ }^{82}$ Maplecroft, map available for registered users at: http://maplecroft.com/about/news/ccvi.html

${ }^{83}$ Dara and the Climate Vulnerable Forum 2012
} 
It is clear that developing countries with considerable emissions reduction potential as well as important adaptation needs are of particular interest, when looking for major synergy and trade-off potentials. Based on the data presented above, these countries include, for example, India, China, Bangladesh, Vietnam and Nepal. Obviously these countries are also at the core of climate negotiations when global emissions reduction gaps are discussed and ways to engage developing countries in emission reduction commitments are debated.

When looking at countries that are most exposed to climate vulnerability and climate change, countries such as Bangladesh, Nepal, Kenya, Ethiopia and Tanzania are of particular interest. In addition to their high vulnerability, they have also demonstrated relatively rapid progress on responding through both mitigation and adaptation strategies.

\subsubsection{Sectors of particular interest when looking for synergies}

With regards to sectors of particular interest, chapter 2 provides a preliminary list of sectors where synergies have so far been identified. However, to date, there are few concrete cases of measured and reported synergies or trade-offs and as mentioned earlier, synergies may also exist in other sectors. When looking at the mitigation potential in non-OECD countries and in economies in transition (EIT), major potential can be identified in the buildings sector, energy supply, agriculture and in industry (see Figure 7). When compared with those sectors identified as having potential for synergies, there are many similarities, with perhaps the waste management sector having the least mitigation potential out of those presented in Figure 7.

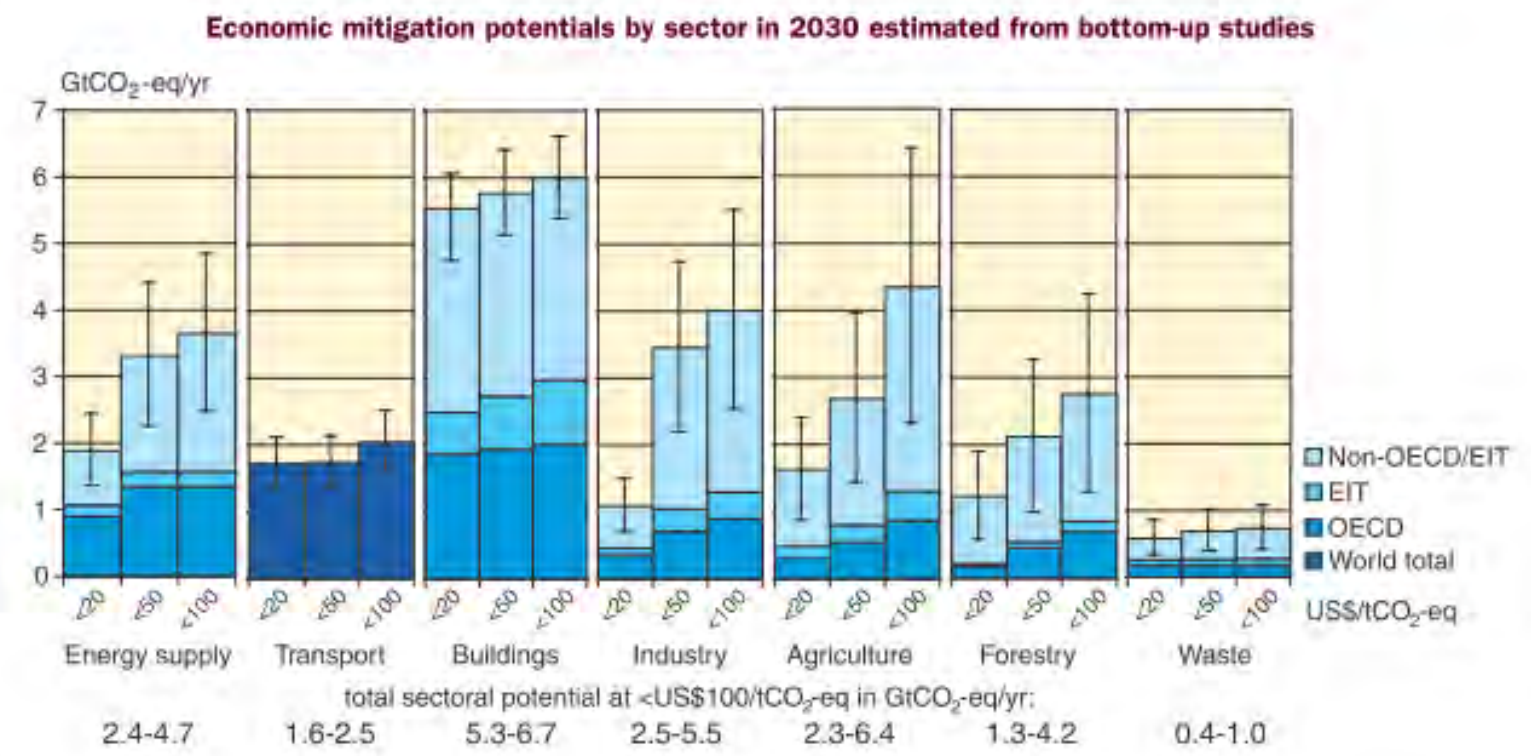

Figure 7. Economic mitigation potentials by sector in 2030 estimated from bottom-up studies (data is modeled with 3 different carbon prices: $<20,<50$ and $<100$ USD $\left./ \mathrm{tCO}_{2}-\mathrm{eq}\right)^{84}$ 
Another way to examine sectors is presented in Figure 8. This data is based on a review of existing National Adaptation Programmes of Action (NAPAs) (as at autumn 2012) from LDCs providing an overview of how different sectors have been prioritized in actions. Even though this analysis does not cover all developing countries, it gives some indication of the sectors where adaptation is considered relevant. Food security and agriculture are most prominent with the water sector and coastal management being prioritized in almost $30 \%$ of NAPAs. By autumn 2012, in line with LDC government requests, food security and agriculture, water resources management, coastal management as well as disaster risk reduction (DRR) have received most of the funding e.g. provided through the Adaptation Fund. ${ }^{85}$

\section{Development sectors prioritized in NAPAs}

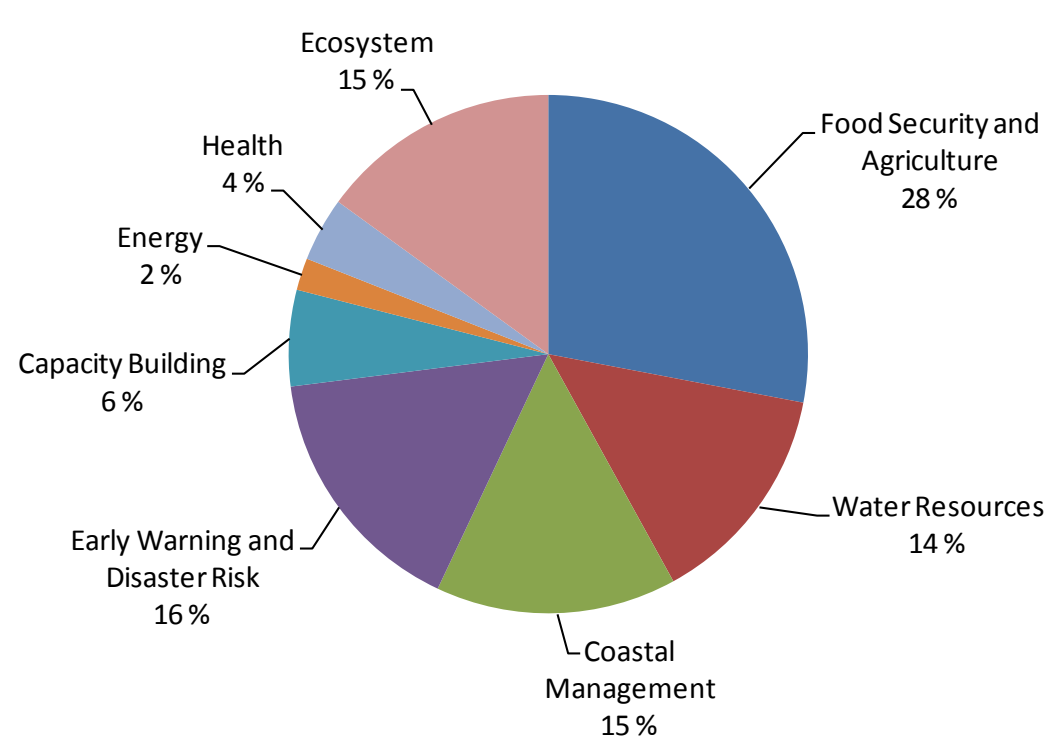

Figure 8. Development sectors prioritized in NAPAs ${ }^{86}$

Table 2 presents the costs of projects identified in NAPA's by sector based on submissions by 38 countries by $2008^{87}$. Based on these cost, it can be seen that the water resources and agriculture/livestock/fisheries sectors are by far receiving the most attention in the reviewed NAPA's representing over $70 \%$ of total costs. By contrast, the energy sector, for which several potential synergies were identified in chapter 2 , corresponds to only $1 \%$ of costs.

It is necessary to point out that the cost estimates in these NAPAs have been produced with quite varying methodologies and data between countries are not fully comparable. In addition, as indicated by the total sum of NAPAs from some 40 countries, the total costs estimates can be considered rather low - they represent preliminary costs estimates for selected priority projects in these LDCs and serve here mainly as an indication of the priority sectors from financing perspective. Table 2

\footnotetext{
${ }^{85}$ GEF 2012

${ }^{86}$ GEF 2012

${ }^{87}$ Biagini et al. 2011
} 
does not include the total costs required to raise the adaptive capacity of these countries to deal with a level of climate change representing a global mean temperature increase of $+2-4{ }^{\circ} \mathrm{C} .{ }^{88}$

Table 2. Cost of projects identified in NAPAs by sector ${ }^{89}$

\begin{tabular}{|l|r|r|}
\hline Sector & Total cost (USD) & Share of total costs (\%) \\
\hline Water resources & 841204099 & $50 \%$ \\
\hline Agriculture/livestock/fisheries & 357840182 & $21 \%$ \\
\hline Coastal management/marine ecosystems & 150823182 & $9 \%$ \\
\hline Terrestrial ecosystems/biodiversity & 132574526 & $8 \%$ \\
\hline Early warning and forecasting & 89531263 & $5 \%$ \\
\hline Health & 46688000 & $3 \%$ \\
\hline Energy & 23514120 & $1 \%$ \\
\hline Education & 21729734 & $1 \%$ \\
\hline Insurance & 8225000 & $0,5 \%$ \\
\hline Tourism & 1850000 & $0,1 \%$ \\
\hline Total & $\mathbf{1 6 7 3 9 8 0 1 0 6}$ & $\mathbf{1 0 0 \%}$ \\
\hline
\end{tabular}

Finally, comparison could also be made between plans and actions that have been identified in NAPAs and NAMAs to identify synergies. A review of 43 NAMAs in $2010^{90}$ categorized the priority activities into different sectors presented in Figure 9.

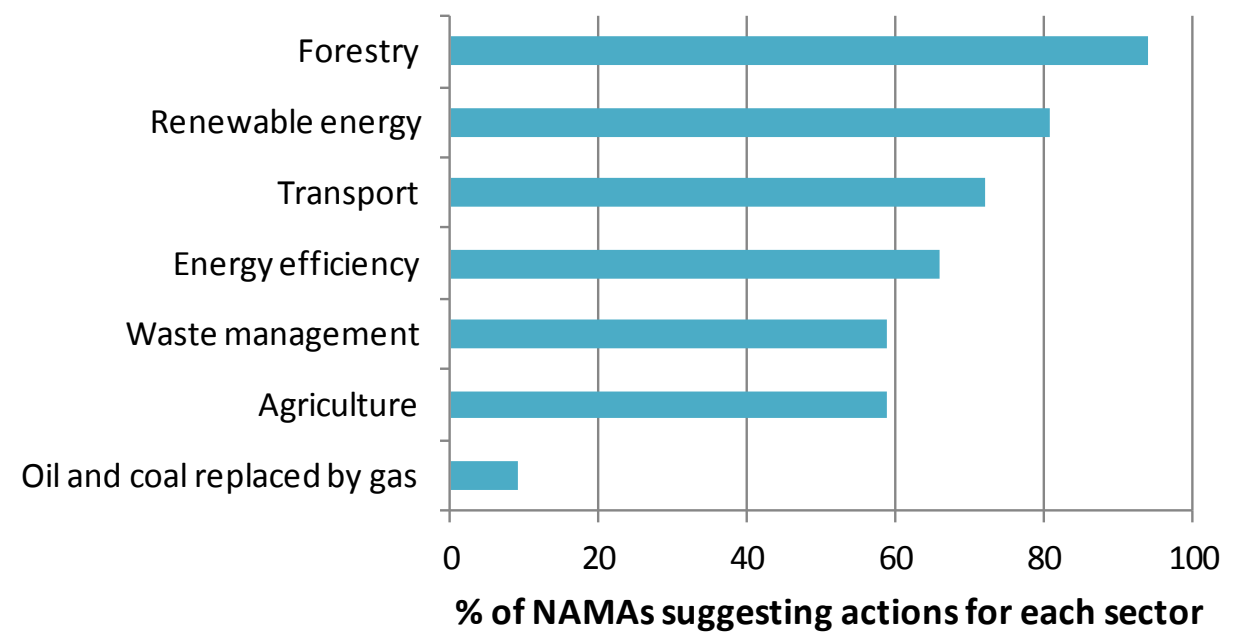

Figure 9. Actions suggested in NAMAs according to sectors ${ }^{91}$

\footnotetext{
${ }^{88}$ E.g. the Climate Vulnerability Monitor's findings imply that it is very unlikely that the adaptation costs currently facing developing countries could be less than 150 billion USD per year (Dara and the Climate Vulnerable Forum 2012).

${ }^{89}$ Biagini et al. 2011. Note the groupings of the sectors can ignite some debate e.g. whether water resources, fisheries and marine ecosystems should indeed be in separate categories. However, the data gives some indication of how different sectors are represented in adaptation programmes.

${ }^{90}$ In November 2012, the amount of NAMAs was 44 (see http://unfccc.int/meetings/cop 15/copenhagen accord/items/5265.php)

${ }^{91}$ Bockel et al. 2011
} 
The figures above present the position of 32 Non-Annex I countries (11 did not describe their proposed actions through the NAMAs letter of agreement). Comparing these sectors with the sectors identified in NAPAs (see Figure 8), it follows that forestry and agriculture are the most common ones where both mitigation and adaptation actions have been identified. This supports the notion that synergies are more likely to be found in sectors that are based on land use. The NAMAs also reflect the argument presented in Chapter 2 that mitigation is often the chosen strategy concerning energybased systems.

Making comparisons between sectors and their adaptation and mitigation potentials is not a straight forward task given the differences in, for example, data parameters and categories of sectors. However, it is fairly safe to say that agriculture and the water sector including coastal management provides relatively high potential for both mitigation and adaptation. Whilst it is premature to assume that this automatically suggests high potential for synergies, there does seem to be some evidence of correlation supported by the several examples of synergies that were identified in existing research. The same kind of reasoning supports the potential for synergies in forestry ( $8 \%$ of NAPA's featuring projects related to terrestrial ecosystems and clearly identifiable mitigation potential). A less obvious sector for adaptation is energy, where both mitigation and adaptation potential has been identified and a number of synergistic options have been studied.

Related to the most vulnerable countries, one could also argue that even though mitigation potential currently may not be as significant, this does not mean that there would not be potential for synergies in the future. Many LDCs are suffering from energy poverty whilst aspiring for growth. Harnessing synergies could be a way to ensure that future growth is sustainable, low-carbon and socially inclusive.

\subsubsection{The particular role or urban areas when looking at synergies and trade-offs}

Over the past 10 years, focus on climate change and the role of cities and urban areas has increased rapidly. This is demonstrated, for example, in the emergence of several initiatives around the topic: UN-Habitat's Cities and Climate Change Initiative launched in 2009, UNEP's launch of a Campaign on Cities and Climate Change, the Asian Cities Climate Change Resilience Network (ACCCRN) launched in 2008, K4C - the Knowledge Centre on Cities and Climate Change, the C40 Climate Leadership Group set up in 2005 and the Urban Climate Change Research Network (UCCRN) that has been running since 2007 , to name a few.

This increased attention is mainly due to the rapid rate of urbanisation occurring all around the world with the population in urban areas exceeding that of rural areas for the first time in $2009^{92}$. Urban areas have become "powerhouses" for new research and innovation ${ }^{93}$ as cities generate more than $80 \%$ of global GDP ${ }^{94}$. At the same time, resources and ecosystems in urban areas are under increasing stress. With rapid urbanisation, the majority $\left(67 \%{ }^{95}\right)$ of energy use is also occurring in

\footnotetext{
92 IEA 2009

${ }^{93}$ United Nations secretary-General's high-level panel on Global sustainability 2012, Lee 2012

${ }^{94}$ Dobbs et al. 2011

${ }^{95}$ Lee 2012
} 
urban areas ${ }^{96}$. This energy use is also driven by a need for new infrastructure to sustain increasing populations ${ }^{97}$. Increased populations and urban development can lead to increased urban heat island effect and increased vulnerabilities to natural disasters (e.g. heat waves ${ }^{98}$ ). Urban sprawl is putting pressure on ecosystems and expanding informal settlements ("slums") are increasing health and security risks as well as exposure to natural disasters ${ }^{99}$.

Urbanisation is therefore leading to increasing emissions in cities and increased vulnerability, especially in developing countries where informal settlements expand, in coastal cities and in waterstressed countries. This suggests that cities could harness synergies in adaptation and mitigation since many cities are already engaged in both activities through the aforementioned climate change initiatives.

As mentioned in Chapter 2, the City of Copenhagen has suggested actions tackling climate change risks that have synergies. Unfortunately there are not many more concrete examples published to date. However, in some cases decision-makers in city administrations are dealing with both adaptation and mitigation, for example, in decision related to land use planning. This makes it more feasible and logical to plan actions that simultaneously reduce emissions and vulnerability. This view and the potential for synergies in urban development have been supported by several of the interviewees consulted in this scoping study. The potential for synergies in developing energy efficient urban housing has been highlighted by many experts.

There is also a need to look trade-offs in cities. For example, increasing densities can have mitigation benefits through decreased need for transportation (among others), but at the same time, decreasing green areas can result in decreased capacity for water absorption and challenges to lead flood waters away. Finding ways to avoid these types of trade-offs presents a lot of potential. More concrete examples need to be identified and analysed in order to provide sound alternatives for urban planning.

\subsection{Financing needs and opportunities for synergies}

\subsubsection{The Global Climate Finance Landscape}

Climate finance refers to financial resources needed to help developing countries mitigate and adapt to impacts of climate change. The principles of the UNFCCC suggest that developed countries mobilise 'new and additional' financial resources to meet the 'incremental costs' of climate change. As the practical interpretation of this principle has remained a source of substantial debate and controversy, several initiatives have been launched in recent years to help clarify the definitions and improve the overall transparency and monitoring of climate finance.

\footnotetext{
${ }^{96}$ IEA 2008

${ }^{97}$ Lee 2012

${ }^{98}$ Lee 2012

${ }^{99}$ United Nations secretary-General's high-level panel on Global sustainability 2012
} 
What is certain is that the international climate finance landscape is extremely complex and rapidly evolving. While within the scope of this study it is neither possible nor necessary to enter into a detailed analysis of this architecture, it is useful to highlight some key features here, to support our review of climate funding opportunities for potential synergies/trade-offs between mitigation and adaptation.

In short, the global climate finance landscape is composed of public funding driven by international climate negotiations and various bilateral initiatives as well as private funding. In most cases identified to date, private funding is driven by private investments in mitigation focused projects. The funding is channeled through a myriad of instruments, which in many cases are difficult to track.

With regards to the amounts of climate funding, by some estimates, the global volumes may already be as high as 96.9 billion USD per year ${ }^{100}$. According to the same estimates the majority of this funding (54.6 billion USD) comes from private funding, mainly focused on mitigation activities (see Figure 10). ${ }^{101}$
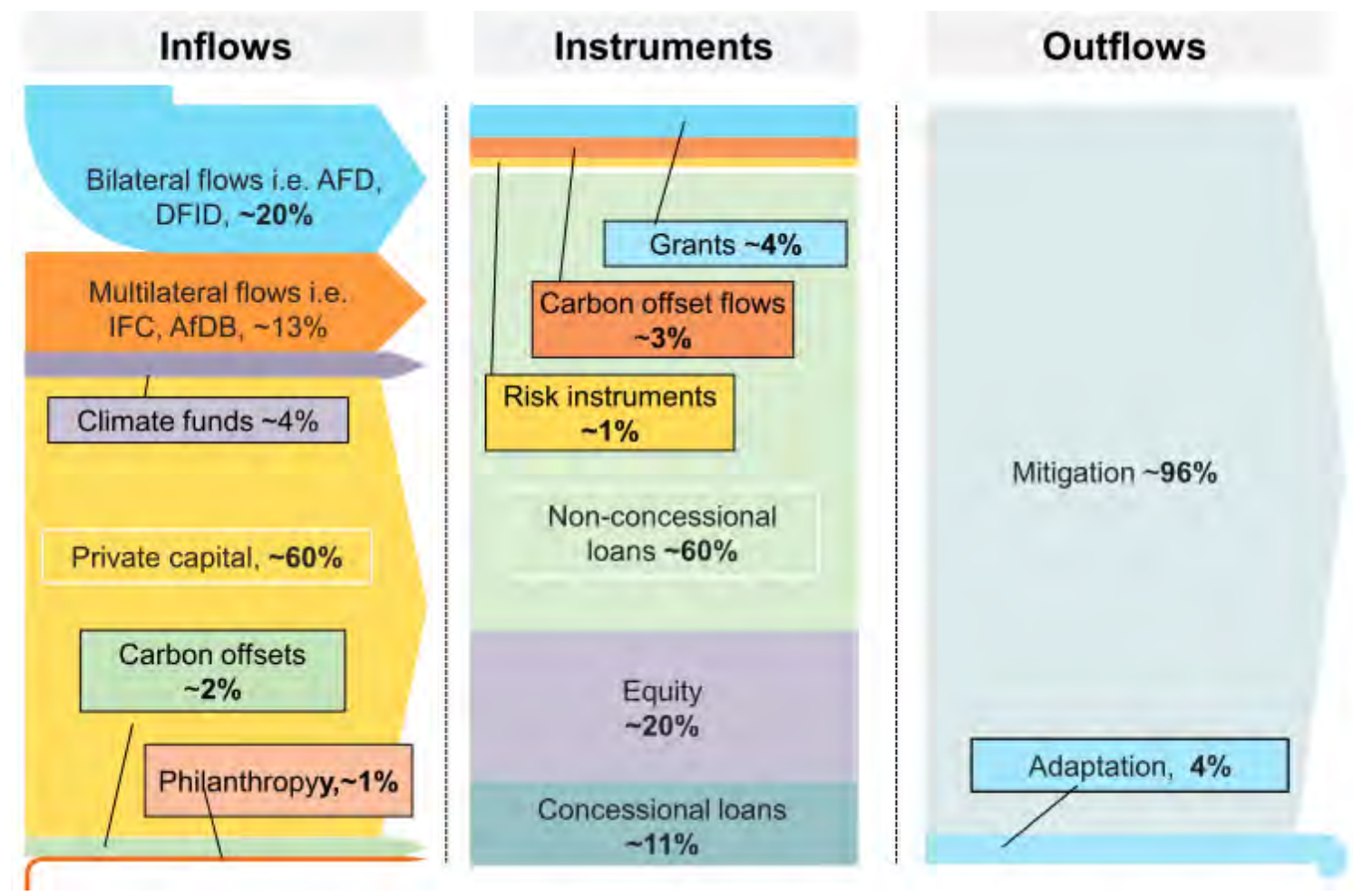

Figure 10. Average disbursements of different forms of climate finance, 2009-2010 102

When comparing the current situation to commitments made, for example, in The 2009 Copenhagen Accord, where developed countries pledged "Fast Start " funds of 10 billion USD a year from 2010 to

\footnotetext{
${ }^{100}$ Buchner et al. 2011

${ }^{101}$ Since the publishing of the data, carbon prices dropped dramatically, however, the value of the carbon market still grew in 2011. By the beginning of 2012, carbon prices were at a record low. (see World Bank report on State and Trends of the Carbon Market 2012 for more information:

(http://siteresources.worldbank.org/INTCARBONFINANCE/Resources/State_and_Trends_2012_Web_Optimized_19035_CV r\&Txt LR.pdf)

102 Ward 2011
} 
2012 , increasing to 100 billion USD per year by 2020 , the picture is rather different. The size and role of private funding can been seen as a positive development, but flows of public funding remain insufficient and the global "emissions gap", i.e. the gap between actual emissions and the emissions levels required in order to have a likely chance of keeping within the $2^{\circ} \mathrm{C}$ limit this century, is growing $^{103}$. Also the true additionality of public funding remains unclear. Recent reviews of the "Fast Start Finance" indicate that the objective of 30 billion USD (balanced between adaptation and mitigation) to flow from developed to developing countries between 2010 and 2012, is unlikely to be met. $^{104}$

Even if public climate finance ${ }^{105}$ (see Annex 2 for a separate presentation of the global architecture of public finance) is proportionally addressing adaptation more than private funding, the overall picture is very clear - the main focus of climate finance to date has been on mitigation. Available reviews of fast start finance flows also point out this imbalance, with some $14 \%$ estimated being for adaptation ${ }^{106}$.

The Green Climate Fund (GCF) ${ }^{107}$, officially launched at the COP-17 in Durban in 2011 aims to address some of the main challenges recognized in the climate finance landscape. Its objective is to play a key role in channeling new, additional, adequate and predictable financial resources (for both adaptation and mitigation) to developing countries. Hereby it should serve to catalyze climate both public and private finance (at the international and national level) and improve the coordination, efficiency and transparency of climate funding. The GCF is also supposed to channel "a significant share of new multilateral funding for adaptation" ${ }^{108}$. In following the transitional process for its full operationalisation possibly by 2014, the content of the GCF and its actual role in improving the climate finance landscape remains to be seen (see also Annex 2).

\subsubsection{Climate funding for harnessing mitigation and adaptation synergies}

Within the current climate finance landscape, funding sources, channels and instruments are geared towards either mitigation or adaptation. There are several reasons for this situation, some of which were highlighted in previous sections of this report. During the scoping study, no funding instruments with explicit and systematic aims to harness synergies (or systematically screening projects/programmes and policies to avoid trade-offs) were identified. However, multiple stakeholders acknowledge the potential for synergies between mitigation and adaptation, and assume the existence of these to some extent in several of their activities. Consequently, the monitoring and reporting efforts of the funding institutions are focused on the primary objectives of the projects and

\footnotetext{
103 UNEP 2011

${ }^{104}$ Dara and the Climate Vulnerable Forum 2012

${ }^{105}$ As an overview, public climate funding, to address mitigation and adaptation challenges in developing countries, is provided through three main pathways, i.e. i) the financial mechanism of the UNFCCC, ii) the mechanisms of the Kyoto Protocol; and iii) bilateral and multilateral channels outside the Convention and its Kyoto Protocol.

${ }^{106}$ Bloomberg 2011

${ }^{107}$ Its legal basis can be found in the Copenhagen Accord adopted during COP-15 in Copenhagen in 2009, and confirmed in the Cancun agreements adopted during COP-16 in Cancun 2010. For further information see http://gcfund.net/home.html ${ }^{108}$ FCCC 2011
} 
initiatives. Hereby co-benefits, be it related to mitigation or adaptation, are rarely measured, reported, nor the potential synergies analyzed and learnt from.

Figure 11 indicates a share of $80 \%$ of funding going for mitigation (of which some $15 \%$ for REDD) and some $15 \%$ for adaptation. $5 \%$ of funds are distributed to projects with multiple foci ${ }^{109}$. The multiple foci slice does not refer to project with explicit aim to address both adaptation and mitigation in a synergetic manner, but to projects not fitting explicitly into either of the main categories. However, amongst the projects categorized by Climate Funds Update under "multiple foci", there are some projects that address both adaptation and mitigation and with some explicitly aiming at integrating the two strategies.

\section{Funding by theme}

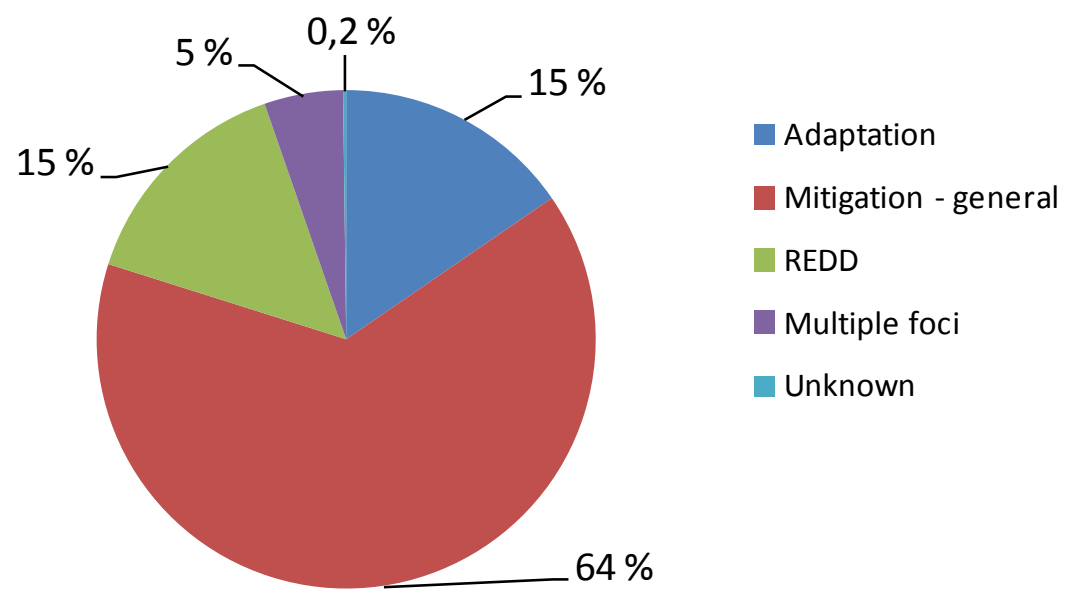

Figure 11. Split of overall funding by theme

Often the division of funding between the categories shown above is based on strict funding criteria of funding organizations, which in many cases guides towards explicitly focusing on adaptation and resilience building, or on achieving cost-efficient mitigation benefits. Our rapid review of selected climate funds (with a particular focus on adaptation and resilience building) provides support for this interpretation. Overall co-benefits are considered a bonus and mitigation (or adaptation) related synergies are mainly seen as just another (non-obligatory) benefit among many other co-benefits. According to several experts interviewed for this study, bilateral actors were considered to have more freedom to be innovative on funding. For example, by mandate the Adaptation Fund is restricted to only focus on adaptation.

In addition to the mandate and criteria driven division, the lack for "synergetic climate funding" (here referring to funding that explicitly aims to harness synergies between mitigation and adaptation) can also be explained by the differing nature of mitigation and adaptation measures. Aspiring for both mitigation and adaptation benefits simultaneously are seen as leading to increasing complexity of initiatives and possibly higher transaction costs. For example, while many adaptation

${ }^{109}$ Climate Funds Update, www.climatefundsupdate.org 
projects can be assumed to have produced mitigation benefits, the process of harnessing additional funding from the reduced emissions or additional carbon sinks created, be it through Certified Emissions Reduction (CER) or Voluntary Emissions Reduction (VER), is often seen as too time consuming and distracting from the primary objective of the project.

When looking from the mitigation perspective, it is interesting to look at the drivers of mitigation, the price of carbon and carbon markets. For example, the Clean Development Mechanism (CDM) has an official dual objective of advancing sustainable development in host countries (Non-annex 1 parties) and contributing to cost efficient GHG mitigation in assisting Annex 1 parties to achieve compliance with their quantified emission limitation and reduction commitments. With regards to CDM, it is important to highlight two aspects. Firstly, synergies with adaptation and resilience building are not part of the CDM criteria. In line with the Marrakesh accords, it is the host country that defines whether or not a project is advancing sustainable development - e.g. African sustainable development criteria typically contain requirements related to income generation, environmental sustainability, employment generation, capacity-building, and technological development. In many cases, the only explicit link with adaptation remains the $2 \%$ funding stream to the Adaptation Fund from CERs. CDM has faced challenges and scrutiny in demonstrating sustainable development benefits ${ }^{110}$. However, any CDM project impacts on, for example, stimulation of job creation and local poverty alleviation, reduction pollution through promotion of renewable and clean energy or the preservation of natural resources, can be considered as contributors to strengthened adaptive capacity. However, these have rarely been measured, reported and verified in a solid manner. Secondly, there seems to be potential to look for concrete synergies more actively, taking note that a major part of funding for CDM has actually been provided by developing countries themselves, being the most vulnerable to climate change.

While REDD+ has many dimensions of relevance for both mitigation and adaptation, it is mainly still driven by and seen as a mitigation tool. While serious concerns over stakeholder participation and the need for safeguards to avoid negative environmental and social impacts are evident, they can also be seen as an indication of REDD+'s relevance for community based adaptation and ecosystem based resilience building. Several bilateral and multilateral funding initiatives have been recently created to support REDD+.

\subsubsection{From project-based funding towards programmatic, sector-wide and whole of government approaches}

The major part of climate funding so far has been channeled through project-based activities. There is an aim to develop more programmatic, sector-wide and policy-level approaches: this is evidenced in the on-going development of Nationally Appropriate Mitigation Actions (NAMAs), National Adaptation Plans (NAPs) as well as amendments to CDM and the development of new market-based instruments. Developing countries are increasingly preparing national strategies that aim to integrate both mitigation and adaptation aspects to the development aspiration, in many cases referring

${ }^{110}$ CDM Policy Dialogue 2012 
to "climate resilient" and "green/low-carbon" growth. ${ }^{111}$ This can be seen as a sign of slow but successful mainstreaming of climate change issues into the development agenda. Entering an era of more programmatic and possibly "whole of government" approaches may allow better identifying and harnessing of synergies, but this will not happen without more in-depth and evidence-based knowledge of the potential synergies and trade-offs, without solving various operational and technical aspects (see Chapter 3.3), increased awareness and capacities - on various levels and among various stakeholders.

When looking into potential synergies between adaptation and mitigation, it is important to note that a large and growing share of climate finance is spent through bilateral development institutions. According to some estimates, 24.6 billion USD per year is directed through bilateral actors ${ }^{112}$. This is clearly a higher share than the funding provided through multilateral institutions (like World Bank / IFC, EIB, EBRD, AfDB, AsDB, IDB). As pointed out above (see also Figure 10), the remainder of climate finance either flows directly through the capital markets, or is provided directly by governments. For example, in Africa, the share of bilateral flows exceeds multilateral flows by a fraction of 8:1 ${ }^{113}$. This point is relevant from the perspective that only a few bilateral actors have successfully put in place solid and systematic climate mainstreaming approaches for their development cooperation organisations, which in most cases, in addition to ODA funding, also serve as the channels and/or decisionmakers for their climate funding. Similarly for multilateral institutions, the climate mainstreaming process, which can serve as basis for identifying and harnessing synergies (or avoiding trade-offs), is only in early stages with the exception of a few forerunners.

\subsection{How to operationalize funding of synergies - challenges and opportuni- ties?}

In the context of carbon finance, "additionality" is often a criteria placed for projects applying for mitigation funding. For example, a CDM project activity is "additional" if GHG emissions are reduced below those that would have occurred in the absence of the registered CDM project activity ${ }^{114}$. Therefore a key question for synergies is what the role of this additionality is and how this would be applied. The requirement for demonstrating additionality of mitigation funding is relatively straight forward (although it may also be complicated in certain circumstances) compared to adaptation. This is mainly because mitigation can be more easily measured through quantitative metrics (reduction of greenhouse gas emission) while there is no such metric for measuring adaptation as most adaptation measures are similar (if not the same) as broader sustainable development actions. The funders of adaptation measures (such as the Adaptation Fund) have struggled to come up with

\footnotetext{
${ }^{111}$ E.g. interesting work is being conducted by countries such as Ethiopia (see The Climate-Resilient Green Economy (CRGE) initiative, http://www.uncsd2012.org/content/documents/287CRGE\%20Ethiopia\%20Green\%20Economy_Brochure.pdf) Kenya (see Kenya Climate Change Action Plan,

http://www.kccap.info/index.php?option=com_phocadownload\&view=category\&id=10\&ltemid=45) and the Philippines (see The Philippines' Climate Change Act, http://cdkn.org/resource/cdkn-inside-story-mainstreaming-climate-resilienceinto-government-the-philippines-climate-change-act/), to mention a few.

112 Buchner et al. 2011

${ }^{113}$ Buchner et al. 2011

${ }^{114}$ FCCC 2006
} 
appropriate metrics for adaptation. The task has not been easy and most funds accept projects and actions that have been "explicitly" designed as adaptation to climate change (even if the actions are similar to development actions). For example, the Nordic Development Fund states that in addition to passing standard economic tests, a criterion is that "at least half of total project costs should be incurred due to the actual or expected impacts of climate change" ${ }^{115}$.

Most mitigation and adaptation projects funded so far have tended to small to medium scale projects. Funds have been committed for either mitigation or adaptation and very seldom both together within the same project. As identified in this scoping study, there are a few sectors where projects could simultaneously integrate both mitigation and adaptation. However, on a project-level synergies may be best sought through taking account of adaptation opportunities (as co-benefits) in mitigation projects or vice versa. Such co-benefit projects are not prevalent yet, and in many cases other than climate-related co-benefits are highlighted (if co-benefits are reported at all).

One possible criterion for identifying and then selecting projects which develop synergies and cobenefits between mitigation and adaptation at the project level may be to require such synergies (and co-benefits) to be identified in the project design stage. While funding could also be made conditional to achieving such synergies, this may require modifications and innovations to funding approaches, e.g. as up-front funding requirements for synergetic projects may be a barrier ${ }^{116}$ and sometimes higher than for dedicated mitigation or adaptation projects. This again raises the question of how to measure achievement as measurement of adaptation on its own remains such a challenge. If an appropriate way to measure adaptation impacts is developed, this will pave the way to responding to the measurement challenge of synergies as well. This requires also the setting of adaptation targets and agreement on indicators. Stadelmann et al (2012) present that adaptation funding could be evaluated according to indicators describing the equity (vulnerability level, poverty and number of beneficiaries) and cost-effectiveness (economic savings and human lives saved) of projects. Their analysis concludes that cost-effectiveness in a purely economic sense is contradictory with equity indicators, unless cost-effectiveness is viewed more broadly e.g. through impacts on human health ${ }^{117}$.

At higher scales of activities (for example, at the level of regional and national development plans) the issue of synergies between mitigation and adaptation could be easier to consider. Increasingly some developing countries are moving towards national climate planning (integrated as part of national development aspirations) where mitigation and adaptation projects can then be funded as part of the plans rather than as stand-alone projects. Combining priority adaptation and mitigation measures in a larger portfolio of projects that are meant to achieve both climate resilient development (adaptation) as well as low Carbon development (mitigation) may serve as the optimal framework for efficient and effective mitigation and adaptation - in many cases being complementary, in some cases also harnessing synergies.

\footnotetext{
${ }^{115}$ NDF 2011

${ }^{116}$ McCarthy, Lipper, Branco 2011

${ }^{117}$ Stadelmann et al. 2012
} 


\section{Conclusions and recommendations}

\subsection{Key findings and conclusions}

Emissions on a global scale continue to rise and impacts of climate change are already being felt. Yet concrete action and required funding for climate change risk management is lagging behind the levels needed to support mitigation and adaptation in order to avoid dangerous levels of climate change. There is an urgent need to seek new funding sources and to ensure that the current and future funding is used in the most efficient and effective manner.

One potential way to address these needs is to systematically promote synergies and avoid tradeoffs among mitigation and adaptation actions. Synergies could enable simultaneous prevention of further emissions increases guiding economies towards low/no-emission pathways as well as accelerating adaptation and required resilience building. This scoping study has explored the opportunities and challenges related to promoting synergies and avoiding trade-offs from the perspective of climate finance.

The literature review acknowledges the evolvement of mitigation and the slow rise of adaptation on the climate policy and finance agenda. It describes the multiple differences between the two main climate risk management approaches. However, it also captures an increasing area of research and also some initiatives in defining and harnessing synergies between mitigation and adaptation. While the landscape of current research remains rather scattered and limited, examples that demonstrate promising potential for accommodating synergies have been identified in several sectors. These sectors include rather obvious candidates such as agriculture, forestry and land use which all play a key role in both mitigation and adaptation. In addition, this study has identified potential for synergies in the energy, infrastructure planning and construction, transportation, insurance and waste treatment sectors. Many of the identified synergies could also encounter trade-offs that need to be avoided.

Developing countries with high (and/or rapidly increasing) emissions and major vulnerabilities are well placed to harness synergies. Promising sectors are those that have a lot of mitigation potential and that have been a focus of national level adaptation plans. In addition, development in urban areas offers ample opportunities to harness synergies in building and infrastructure development. Where synergies have been identified, they have often resulted in more effective climate policy and provided co-benefits with other goals of sustainable development. The reviewed literature, and in particular, the multiple stakeholders consulted in this study recognize the potential of synergies and view these as a promising area that merits further attention.

While the pool of current research clearly indicates that these synergies exist, assessing the magnitude of the potential and the associated costs and benefits remains a challenge. This type of assessment is needed in order to understand under which conditions, in which sectors and based on which criteria it is wise to explicitly seek out these synergies. If synergies are explicitly sought without this type of proper assessment, there is a risk that implementation will encounter major difficulties leading to inefficiencies. These inefficiencies can include higher transaction costs due to an increase in the stakeholders involved and more complexity in project planning and evaluation. These concerns could be addressed by piloting synergistic projects in those sectors and activities identified 
as having potential (e.g. forestry, agriculture and energy efficient buildings). Building on this evidence base would provide more concrete examples of the associated opportunities and challenges.

With regards to the climate finance landscape, current funding sources, channels and instruments are geared towards either mitigation or adaptation, primarily based on strict funding criteria of most funding organizations. The major part of climate funding to date has been channeled through project-based activities. During the scoping study, no funding instruments with explicit and systematic aims to harness synergies (or systematic screening projects/programmes and policies to avoid trade-offs) were identified. However, many of the experts interviewed in this study assume the existence of synergies to some extent in several of their activities. Highlighted challenges include the lack of a solid approach to measuring, reporting and verifying adaptation impacts and therefore being able to assess synergies. In addition, strict funding criteria can restrict focusing on synergies.

Developing countries are increasingly preparing national strategies that aim to integrate both mitigation and adaptation aspects to the development aspiration. This can be seen as a sign of slow but successful mainstreaming of climate change issues into various sectors, and more broadly into the development agenda. Entering an era of more programmatic and possibly "whole of government" approaches may allow better identifying and harnessing of synergies. This will not happen without more in-depth and evidence-based knowledge of the potential synergies and trade-offs, without solving various operational and technical aspects, or without increased awareness and capacities on various levels (be it local, regional, national or international) and among various stakeholders.

\subsection{Recommendations}

\subsubsection{General recommendations}

This scoping study has reviewed the potential role that harnessing mitigation and adaptation synergies could have in addressing the existing mitigation and adaptation gaps and ensuring efficient and effective use of climate finance. It has concluded that synergies can play a promising and important role in responding to climate change and in forming climate policy, that the profile of synergies needs to be raised, and that the topic requires further attention. Based on the literature review and selected stakeholder interviews the following recommendations are given:

Recommendation 1: More empirical research on synergies needs to be conducted to further define and concretize the benefits and challenges.

Further research on existing cases will allow showcasing under which criteria and how synergies can be harnessed and trade-offs avoided in the best possible way. This will help tackle any concerns related to potential inefficiencies and to address other remaining challenges in for example project planning. This research needs to draw out the possibilities and differences in various countries, regions, and under different climate scenarios. A broader range and depth of solid case studies can add focus to policy decisions and clarity to responding effectively to climate change risks. Further research should also provide suggestions for concrete entry points (for example, when rebuilding infrastructures, planning and reviewing policies etc.) for integrating adaptation and mitigation and harnessing any synergies.

Recommendation 2: A review of the funding criteria of relevant climate funds could be carried out. 
Findings in this study indicate that a hindrance to focus funding on synergies lies in the criteria for many of the existing climate funds. One way of addressing this would be to closely examine the current funding criteria for the most important climate funds that have a suitable mandate to look at synergies. These could be analyzed according to how possible synergies are currently addressed, reported and/or valued and more importantly, how the funding criteria might be adjusted to allow for funding of synergies. Based on this scoping study, it is difficult to find solid argumentation for establishing a new fund explicitly focusing on funding synergies. However, reviewing the possibility and interest of existing funds to study their criteria and to review and analyze synergies (and tradeoffs) in their existing portfolios, could serve as a reinforcing approach.

Recommendation 3: The concept of synergies should be linked with the climate mainstreaming agenda to serve broader climate change objectives.

Efforts invested into demonstrating mitigation and adaptation synergies should not distract attention away from the on-going climate change risk management activities. However, if properly addressed, synergies can serve as one component in building the necessary knowledge base, institutional capacity and sectoral collaboration that effective climate policy will require. In particular, comprehensive mainstreaming of climate change into various sectors, policies and development plans will need to better understand the interlinkages between various climate mitigation and adaptation measures as well as interlinkages with other policy areas. This is a precondition for advancing from mainly project-based climate activities into more comprehensive, climate mainstreamed action.

Recommendation 4: Attention should be paid to opportunities to catalyze private sector climate action and its role in harnessing synergies.

To date, market-based instruments (in particular CDM) have a rather mixed track record in reducing global emissions or providing sustainable development benefits. However, important lessons have been learned and improvements are being introduced into existing instruments and new ones are being developed. As the role of the private sector will remain central, in ensuring sufficient climate funding as well as efficient and effective implementation, its role in systematically harnessing any synergies - including synergies between mitigation and adaptation - should be better understood. What value could the private sector gain from synergies and what means could they offer to harnessing them are relevant questions. Innovation and application of new technology, penetration of innovative low/no-carbon products, services and ways of living are highly dependent on private sector investments and design of new private sector business models. The role of public climate finance remains catalytic and crucial in building enabling environments and capacities (knowledge, awareness, institutions, policy instruments etc) that guide (and reward) private sector funding to mainstream mitigation and adaptation aspects in their business development and investment decisions in developing countries.

\subsubsection{Nordic value added - how could the Nordic countries contribute}

In addition to the recommendations above, there are some particular areas that could be of interest for the Nordic countries and where NOAK could play a key role. Nordic countries are well positioned to contribute to climate action in developing countries. Joint action could provide more added value compared to stand-alone action by each Nordic country on its own. In the following, some additional dimensions to the recommendations above are described. 
Firstly, the Nordic countries have representation in various climate funds and a joint position on the issue of synergies could be influential. Nordic countries have several options for delivering funds to developing countries to tackle climate change. For example, The Green Climate Fund is set up to finance both mitigation and adaptation and will absorb at least part of the envisioned 100 billion USD by 2020 (The 2009 Copenhagen Accord) pledge and also some of the existing climate financing mechanisms. The fund is currently under establishment and financing criteria is still not developed. It is not yet clear how the issue of adaptation-mitigation synergies will be addressed when criteria are developed. Three out of the 24 members of the recently established board come from Nordic countries (Denmark, Norway, Sweden), and a potential common Nordic approach to the issue of synergies could be valuable. Obviously other funds could also be of particular Nordic interest, e.g. the Nordic Development Fund (through its Nordic Climate Facility) has provided funding for innovative mitigation and adaptation initiatives, which in many cases have simultaneously promoted both mitigation and adaptation ${ }^{118}$.

Secondly, the Nordic countries have particular expertise in some sectors, which could serve developing countries in addressing their priority climate challenges including placing stronger focus on synergies. For example, forestry, agriculture, and distributed energy solutions present various opportunities for adaptation and mitigation synergies, and hereby could contribute to both low-carbon growth as well as resilience building in developing countries. The Nordic countries have vast experience in these sectors, which have also remained at the core of most Nordic country ODA funding during the past decades. Taking note of the rapid urbanization in developing countries, many of the climate challenges will have to be addressed in urban areas. Land-use management and urban planning and the related potential synergies and trade-offs might be another area of joint interest for Nordic countries. Learning from synergies and trade-offs in developing countries can also serve developed countries and vice versa. From a practical point of view, The Nordic Partnership Initiative on Up-scaled Mitigation Action (NPI) could serve as an example for a potential in-depth study on synergies and trade-offs and a potential pilot.

Thirdly, with all the Nordic countries actively working on climate mainstreaming of their development cooperation, synergies could be seen as an opportunity for more comprehensive climate change action. In particular, there is an opportunity to increasingly move from stand-alone projectbased climate action (whether adaptation or mitigation or the two combined) towards supporting broader, sector-wide and national-level action plans. Several developing countries are moving toward a more strategic approach to development planning. Funding decisions could consider how countries are planning to address both mitigation and adaptation instead of looking at individual projects. This will mean devolving funding allocation decisions to the national level where they are likely to be more effective rather than retaining them at the donor level. Funding broader action plans could be more effective than pushing for separate initiatives that focus only on synergistic activities. The rapidly evolving climate finance landscape with the accelerating creation of national trust funds for climate change (e.g. Bangladesh, Indonesia, Brazil, China, Ecuador, Guyana, the Maldives and Thailand have already created such funds and some others including Rwanda, Kenya, and Tanzania are considering them) could serve as vehicles for such support to developing countries.

${ }^{118}$ See http://www.ndf.fi/index.php?id=22 


\section{References}

Ayers Jessica M. and Huq Saleemul (2008), The Value of Linking Mitigation and Adaptation: A Case Study of Bangladesh, Environmental Management, volume 43, issue 5:753-764.

Biagini Bonizella, Christiansen Lars, Dobardzic Saliha, Moore Rawleston (2011), Strategy on Adaptation to Climate Change for the Least Developed Countries Fund (LDCF) and the Special Climate Change Fund (SCCF), Global Environment Facility, May 2011.

Bloomberg (2011), Have developed nations broken their promise on \$30bn 'fast-start' finance? Bloomberg New Energy Finance White Paper, September 2011.

Bockel Louis, Gentien Armel, Tinlot Marianne, Bromhead Marjory (2011), From Nationally Appropriate Mitigation Actions (NAMAs) to Low-Carbon Development in Agriculture: NAMAs as a pathway at country level, EASYPol Issue Paper, Module 103, for the Food and Agriculture Organisation of the United Nations, May 2011.

Bournay Emmanuelle (2008), Kick the Habit: A UN Guide to Carbon Neutrality, UNEP/GRID-Arendal.

Buchner Barbara, Falconer Angela, Herve-Mignucci Morgan, Trabacchi Chiara, Birkman Marcel (2011), The Landscape of Climate Finance, Climate Policy Initiative, October 2011.

CDM Policy Dialogue (2012), Climate Change, Carbon Markets and the CDM: A Call to Action, Report of the High-Level Panel on the CDM Policy Dialogue, Luxembourg 2012.

Dang Hanh H., Michaelowa Axel, Tuan Dao D. (2003), Synergy of adaptation and mitigation strategies in the context of sustainable development: the case of Vietnam, Climate Policy 3 (2003), Supplement 1: S81-S96.

Dara and the Climate Vulnerable Forum (2012), Climate Vulnerability Monitor $2^{\text {nd }}$ Edition: A Guide to the Cold Calculus of a Hot Planet, Fundacion DARA Internacional.

Dobbs Richard, Smit Sven, Remes Janna, Manyika James, Roxburgh Charles, Restrepo Alejandra (2011), Urban world: Mapping the economic power of cities, McKinsey Global Institute, March 2011.

EPIC (2012), Climate Smart Agriculture: Capturing the synergies among mitigation, adaptation and food security in Malawi, Vietnam and Zambia, Project Brief, available online at: http://www.fao.org/climatechange/epic/en/ (viewed 27.9.2012).

FAO (2009), Food Security and Agricultural Mitigation in Developing Countries: Options for Capturing Synergies, Food and Agriculture Organization of the United Nations, October 2009.

FCCC (2006), Report of the Conference of the Parties serving as the meeting of the Parties to the Kyoto Protocol on its first session, held at Montreal from 28 November to 10 December 2005, Addendum Part Two: Action taken by the Conference of the Parties serving as the meeting of the Parties to the Kyoto Protocol at its first session, Decisions adopted by the Conference of the Parties serving as the meeting of the Parties to the Kyoto Protocol, FCCC/KP/CMP/2005/8/Add.1 
FCCC (2011), Report of the Conference of the Parties on its sixteenth session, held in Cancun from 29 November to 10 December 2010, Addendum Part Two: Action taken by the Conference of the Parties at its sixteenth session, Decisions adopted by the Conference of the Parties, FCCC /CP/2010/7/Add.1

Global Environment Facility (2012), Least Developed Countries Fund website, available at: http://www.thegef.org/gef/LDCF (viewed 15.11.2012).

Hagström Markku, Illman Julia, Pesola Aki, Vanhanen Juha, Gilbert Ylva (2011), Carbon footprint of construction, operation and maintenance of roads and railways, Finnish Transport Agency, Infrastructure Technology, Research report 38/2011.

Illman Julia, Kumpulainen Anna, Pesola Aki, Vanhanen Juha (2012), Carbon footprint of construction, operation and maintenance of waterways and traffic, Finnish Transport Agency, Infrastructure Technology, Research report 21/2012.

Intergovernmental Panel on Climate Change (2001a), Climate Change 2001: Synthesis Report. A Contribution of WorkingGroups I, II, III to the Third Assessment Report of the Intergovernmental Panel on Climate Change, R.T.Watson and the Core Team, Eds., CambridgeUniversity Press, Cambridge and New York, $398 \mathrm{pp}$.

International Energy Agency (2008), World Energy Outlook 2008, OECD/IEA.

International Energy Agency (2009), World Energy Outlook 2009, OECD/IEA.

Jones Roger (2003), Managing Climate Change Risks, OECD Workshop on the Benefits of Climate Policy, Improving Information for Policy Makers, OECD ENV/EPOC/GSP(2003)22/FINAL.

Klein Richard J.T. (2007a), Links between Adaptation to and Mitigation of Climate Change, Third Workshop, Session 3: Addressing Action on Adaptation conference presentation, Bonn Germany 17.5.2007.

Klein Richard J.T., Huq Saleemul, Denton Fatima, Downing Thomas E., Richels Richard G., Robinson John B., Toth Ferenc L. (2007b), Inter-relationships between adaptation and mitigation. Climate Change 2007: Impacts, Adaptation and Vulnerability. Contribution of Working Group II to the Fourth Assessment Report of the Intergovernmental Panel on Climate Change, M.L. Parry, O.F. Canziani, J.P. Palutikof, P.J. van der Linden and C.E. Hanson, Eds., Cambridge University Press, Cambridge, UK, 745777.

Klein Richard J.T., Schipper Lisa E., Dessai Suraje (2003), Integrating mitigation and adaptation into climate and development policy: three research questions, Tyndall Centre Working Paper No. 40, November 2003.

La Rovere Emilio Lebre, Avzaradel Ana Carolina, Monteiro Joyce Maria Guiraraes (2009), Potential synergy between adaptation and mitigation strategies: production of vegetable oils and biodiesel in northeastern Brazil, Climate Reasearch 40 (2009):233-239.

Larsen Sanne Vammen, Kørnøv Lone, Wejs Anja (2012), Mind the gap in SEA: An institutional perspective on why assessment of synergies amongst climate change mitigation, adaptation and other 
policy areas are missing, Environmental Impact Assessment Review, Volume 33, Issue 1, February 2012.

Lee Marcus (2012), Cities and Climate Change, UNU-WIDER Conference 2012, Climate Change and Development Policy, Greening Cities in Developing Countries, Urban Development Unit, The World Bank.

Locatelli Bruno, Evans Vanessa, Wardell Andrew, Andrade Angela, Vignola Raffaele (2011), Forests and Climate Change in Latin America: Linking Adaptation and Mitigation, Forests 2 (2011):431-450.

Mata Luis J. and Budhooram June (2007), Complementarity between mitigation and adaptation: the water sector, Mitigation and Adaptation Strategies for Global Change 12 (2007):799-807.

McCarthy Nancy, Lipper Leslie, Branca Giacomo (2011), Climate-Smart Agriculture: Smallholder Adoption and Implications for Climate Change Adaptation and Mitigation, Food and Agriculture Organization of the United Nations (FAO), December 2011.

Mills Evan (2007), Synergisms between climate change mitigation and adaptation: an insurance perspective, Mitigation and Adaptation Strategies for Global Change 12 (2007):809-842.

Mitchell Tom and Maxwell Simon (2010), Defining Climate Compatible Development, CDKN ODI Policy Brief, November 2010.

Moser Susanne C. (2011), Adaptation, mitigation, and their disharmonious discontents: An essay, Climatic Change, volume 111, no. 2:165-175.

Muys Bart, Akinnifesi Festus, Verbist Bruno (no date), Integration of Climate Change Mitigation and Adaptation Strategies in the South, Department of Earth and Environmental Sciences K.U. Leuven, Belgium, available online at:

http://www.biw.kuleuven.be/lbh/lbnl/forecoman/klimos/presentaties/6 Muys Adaptation strategi es ppt\%20KAOW.pdf (viewed 27.9.2012).

NDF (2011), Identification and Screening of Climate Projects: Summary, Nordic Development Fund, January 2011.

OECD (2008), OECD Environmental Outlook to 2030, Summary in English, OECD.

Olivier Jos G.J., Janssens-Maenhout Greet, Peters Jeroen A.H.W. (2012), Trends in global $\mathrm{CO}_{2^{-}}$ emissions: 2012 Report, Background studies, The Hague: PBL Netherlands Environmental Assessment Agency; Ispra Joint Research Centre.

Rosenzweig Cynthia and Tubiello Francesco Nicola (2007), Adaptation and mitigation strategies in agriculture: an analysis of potential synergies, Mitigation and Adaptation Strategies for Global Change 12 (2007):855-873.

Stadelmann Martin, Persson Åsa, Ratajczak-Juszko Izabela, Michaelowa Axel (2012), Equity and costeffectiveness of multilateral adaptation finance - are they friends or foes? CIS Working Paper $\mathrm{nr}$ 73, 2012, Center for Comparative and International Studies (ETH Zurich and University of Zürich). 
Stern Nicholas (2007), The Economics of Climate Change: The Stern Review, Cambridge University Press.

Stripple Håkan and Uppenberg Stefan (2010), Life cycle assessment of railways and rail transports: Application in environmental product declarations (EPDs) for the Bothnia Line, Swedish Environmental Research Institute, Report B1943.

Swart Rob (2008), Climate change versus development: trade-offs and synergies, Policy Network, available online at: $\underline{w w w}$.policy-network.net/publications download.aspx?ID=2188 (viewed 27.9.2012).

Swart Rob and Raes Frank (2007), Making integration of adaptation and mitigation work: mainstreaming into sustainable development policies? Climate Policy 7 (2007):288-203.

UNEP (2011), Bridging the Emissions Gap: A UNEP Synthesis Report, United Nations Environment Programme, November 2011

United Nations secretary-General's high-level panel on Global sustainability (2012), Resilient People, Resilient Planet: A future worth choosing. New york: United Nations.

U.S. Energy Information Administration (2010), International Energy Statistics: Total Carbon Dioxide Emissions from the Consumption of Energy (Million Metric Tons), All Countries year 2010, available online at: http://www.eia.gov/cfapps/ipdbproject/IEDIndex3.cfm?tid=90\&pid=44\&aid=8 (viewed 18.10.2012)

Verchot Louis V., van Noordwijk Meine, Kandji Serigne, Tomich Tom, Ong Chin, Albrecht Alain, Mackensen Jens, Bantilan Cynthia, Anupama K.V., Palm Cheryl (2007), Climate change: linking adaptation and mitigation through agroforestry, Mitigation and Adaptation Strategies for Global Change 12 (2007):901-918.

Ward John (2011), Kenya Climate Change Action Plan, Annex A: Current and future international climate finance architecture: implications for Kenya's financing mechanism, Report prepared for Government of Kenya, Vivid Economics, November 2011, available online at:

http://www.kccap.info/index.php?option=com phocadownload\&view=category\&id=10\&ltemid=45 (viewed 22.10.2012).

Willbanks Thomas J. and Sathaye Jayant (2007), Integrating mitigation and adaptation as responses to climate change: a synthesis, Mitigation and Adaptation Strategies for Global Change 12 (2007):957-962.

Willbanks Thomas J., Kane Sally M., Leiby Paul N., Perlack Robert D., Settle Chad, Shogren Jason F., Smith Joel B. (2003), Possible Responses to Global Climate Change: Integrating Mitigation and Adaptation, Environment vol. 45 no. 5:29-38.

Willbanks Thomas J., Leiby Paul, Perlack Robert, Ensminger Timothy J., Wright Sherry B. (2007), Toward an integrated analysis of mitigation and adaptation: some preliminary findings, Mitigation and Adaptation Strategies for Global Change 12(2007), issue 5:713-725. 
World Bank (2010), The Economics of Adaptation to Climate Change, A Synthesis Report, Final consultation draft, August 2010, The World Bank, available online at:

http://siteresources.worldbank.org/EXTCC/Resources/EACC FinalSynthesisReport0803 2010.pdf (viewed 27.9.2012).

World Commission on Dams (2000), Dams and Development: A new framework for decision-making, Earthscan Publications Ltd. November 2000.

Internet sources:

CDKN website: $\underline{\text { http://cdkn.org/?loclang=en gb }}$

Climate Funds Update: http://www.climatefundsupdate.org/themes

Finn Church Aid website:

http://www.kua.fi/en/where we work/advocacy work/climate change in our work/?id=2151

Global Alliance for Clean Cookstoves: http://www.cleancookstoves.org/

Kenya Climate Change Action Plan:

http://www.kccap.info/index.php?option=com phocadownload\&view=category\&id=10\&ltemid=45

Maplecroft, map available for registered users at: http://maplecroft.com/about/news/ccvi.html

Merriam Webster Online Dictionary http://www.merriam-webster.com/dictionary/synergy

Nordic Development Fund project descriptions: Off-grid Electrification Using Wind and Solar Energy in Kenya (http://www.ndf.fi/index.php?id=123) or Sustainable Electrification and Renewable Energy Programme in Nicaragua (http://www.ndf.fi/index.php?id=57)

The Climate-Resilient Green Economy (CRGE) initiative:

http://www.uncsd2012.org/content/documents/287CRGE\%20Ethiopia\%20Green\%20Economy Broc hure.pdf

The Philippines' Climate Change Act: http://cdkn.org/resource/cdkn-inside-story-mainstreamingclimate-resilience-into-government-the-philippines-climate-change-act/ 


\section{Annex 1: List of people consulted}

Jiwan Acharya

Aaron Atteridge

Alice Caravani

Harald Dovland

Christoph Feldkötter

Elisabeth Folkunger

Seraphine Haeussling

Jochen Harnisch

Torleif Haugland

Ari Huhtala

Hans Olav Ibrekk

Markku Kanninen

Marianne Karlsen

Leena Klossner

Axel Michaelowa

Matti Nummelin

Mikko Ollikainen

Johanna Pietikäinen

Kjell Roland

John Magne Skjelvik

Frank Sperling

Folke Sundman

Roland Sundström

Marja-Liisa Tapio-Biström

Jeremy Warford

Tom Wilbanks

Steven Rone Wilson
Asian Development Bank (ADB)

Stockholm Environment Institute (SEI)

Overseas Development Institute (ODI)

Carbon Limits

Deutsche Gesellschaft für Internationale Zusammenarbeit (GIZ) GmbH

Swedish International Development Cooperation Agency (SIDA)

United Nations Environment Programme (UNEP)

KfW Entwicklungsbank

Carbon Limits

The Climate and Development Knowledge Network (CDKN)

Ministry of Foreign Affairs, Norway

Viikki Tropical Resources Institute (VITRI) University of Helsinki

Ministry of Environment, Norway

Nordic Development Fund (NDF)

Institute of Political Science, University of Zurich and Center for Comparative and International Studies (CIS)

Ministry for Foreign Affairs, Finland

Adaptation Fund

Ministry for Foreign Affairs, Finland

Norfund (Norwegian Investment Fund for Developing Countries)

Vista Analyse AS

African Development Bank Group (AfDB)

Ministry for Foreign Affairs, Finland

Global Environment Facility (GEF)

Food and Agriculture Organisation of the United Nations (FAO)

Nordic Development Fund (NDF)

Oak Ridge National Laboratory

Inter-American Development Bank, Multilateral Investment Fund (IADB/MIF) 


\section{Annex 2. Overview of the global architecture of public finance}

Source: Climate Funds Update (http://www.climatefundsupdate.org )

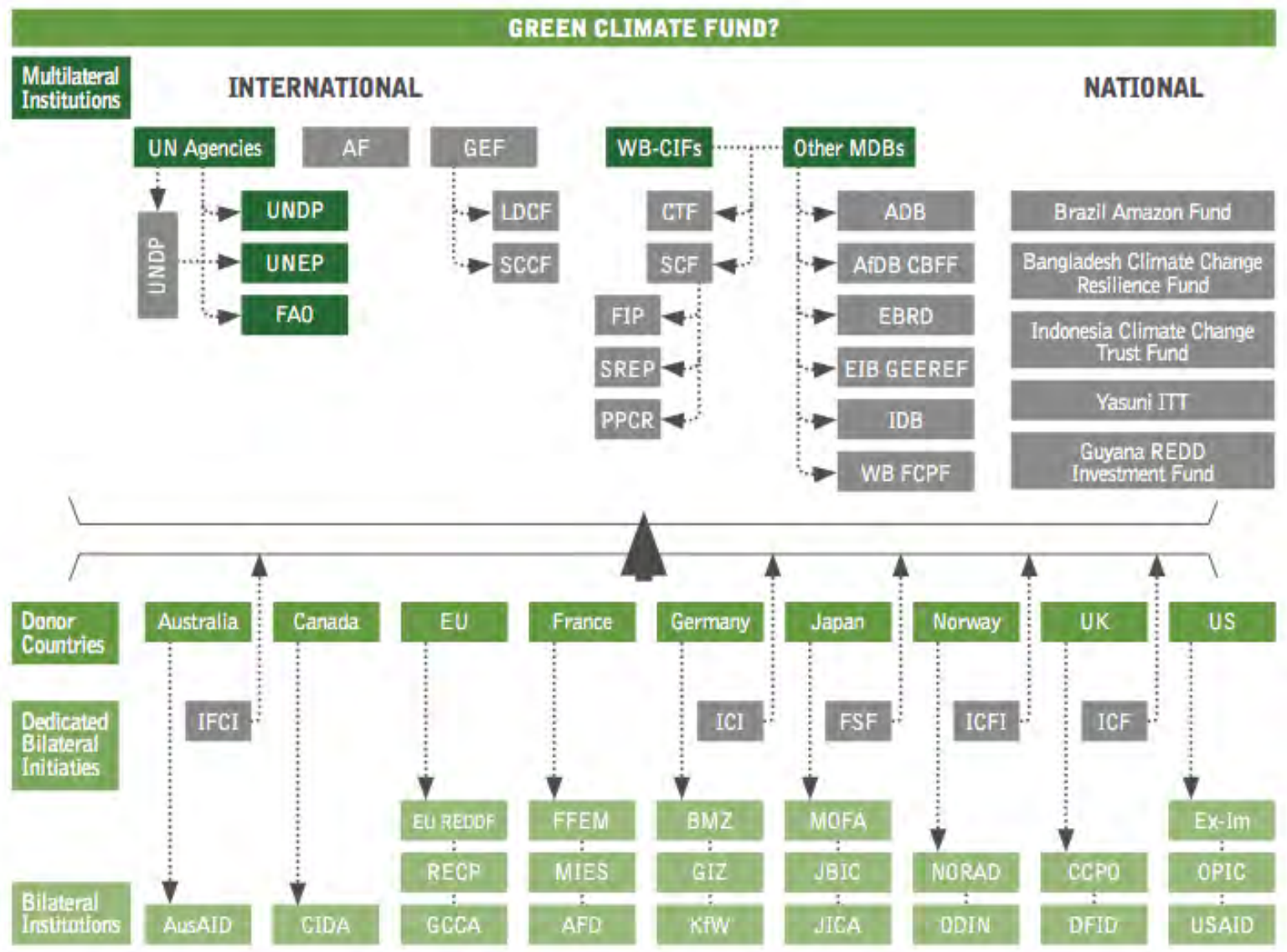

Government agencies, development banks and Multilateral funds programmes

- AFD - French Development Agency

- AusAID - Australian Agency for International Development

- $\quad$ BMZ - Federal Ministry for Economic Cooperation and Development

- CCPO - Climate Change Projects Office

- CIDA - Canadian International Development Agency

- DFID - Department for International Development

- EU REDDF - European Union REDD Facility
- $\quad$ AF - Adaptation Fund

- APCF - Asia Pacific Carbon Fund

- CBFF - Congo Basin Forest Fund

- CTF - Clean Technology Fund

- FCPF - Forest Carbon Partnership Facility

- FIP - Forest Investment Program

- GEEREF - Global Energy Efficiency and Renewable Energy Fund

- LDCF - Least Developed Countries Fund

- PPCR - Pilot Program on Climate Resilience

- $\quad$ SCCF - Special Climate Change Fund

- SCF - Strategic Climate Fund 
- Ex-Im - Export-Import Bank of the United States

- $\quad$ FFEM - French Global Environment Facility

- GCCA - Global Climate Change Alliance

- GIZ - German Technical Cooperation

- JBIC - Japan Bank of International Cooperation

- JICA - Japan International Cooperation Agency

- KfW - German Development Bank

- MIES - Interministerial Taskforce on Climate Change

- MOFA - Ministry of Foreign Affairs

- NORAD - Norwegian Agency for Development Cooperation

- ODIN - Ministry of Foreign Affairs

- OPIC - Overseas Private Investment Corporation

- RECP - Africa-EU Renewable Energy Cooperation Programme

- USAID - U.S. Agency for International Development

\section{Dedicated bilateral initiatives}

- $\quad$ FSF - Fast Start Finance (Japan)

- ICF - International Climate Fund (UK)

- ICFI - International Climate Forest Initiative (Norway)

- $\quad$ ICI - International Climate Initiative (Germany)

- $\quad$ IFCI - International Forest Carbon Initiative (Australia)
- $\quad$ SREP - Scaling-Up Renewable Energy Program

UN and regional agencies, other acronyms

- AfDB - African Development Bank

- AsDB - Asian Development Bank

- CIF - Climate Investment Funds

- EBRD - European Bank for Reconstruction and Development

- EIB - European Investment Bank

- FAO - Food and Agriculture Organization

- UNDP - United Nations Development Programme

- UNEP - United Nations Environment Programme

- UNREDD - United Nations Collaborative Programme on Reducing Emissions from Deforestation and Forest Degradation

- WB - World Bank 


\section{Annex 3. List of Acronyms}

ACCCRN Asian Cities Climate Change Resilience Network

AFD L' Agence Française de Développement

AfDB African Development Bank

AsDB $\quad$ Asian Development Bank

CCD Climate Compatible Development

CDKN Climate and Development Knowledge Network

CDM Clean Development Mechanism

CER Certified Emissions Reduction

COP Conference of the Parties

CRGE Climate Resilient Green Economy initiative

DFID Department for International Development

DRR Disaster Risk Reduction

EBRD European Bank for Reconstruction and Development

EIB European Investment Bank

EIT Economies in Transition

GCF Green Climate Fund

GDP Gross Domestic Product

GHG Greenhouse Gas

IFC International Finance Corporation

IPCC Intergovernmental Panel on Climate Change

LDC Least Developed Country

MRV Measurable, Reportable and Verifiable

NAMA Nationally Appropriate Mitigation Action

NAP National Adaptation Plan

NAPA National Adaptation Programme of Action

NCM Nordic Council of Ministers

NGO Non-Governmental Organisation

NOAK The Nordic Working Group for Global Climate Negotiations

NPI Nordic Partnership Initiative 
ODA Official Development Assistance

OECD Organisation for Economic Co-operation and Development

REDD Reduced Emissions from Deforestation and Forest Degradation

UCCRN Urban Climate Change Research Network

UNEP United Nations Environment Programme

UNFCCC United Nations Framework Convention on Climate Change

UN-Habitat United Nations Human Settlements Programme

VER Voluntary Emissions Reduction 


\section{Annex 4: Presentation of the project team}

\section{Ms. Julia IIIman}

Ms. Illman has extensive expertise in identifying emissions reduction potentials, target setting and developing indicators for measuring progress in achieving emission reducing targets. She has also worked on mainstreaming climate change considerations into investment decision-making, project planning and implementation. She has previously worked as a sustainability consultant in the United Kingdom and with UN-HABITAT in Kenya researching climate change mitigation and adaptation in poor urban settlements.

\section{Mr. Mikko Halonen}

Mr. Halonen has a strong background in international and national climate policy analysis \& development (incl. mitigation and adaptation). He has participated in climate research programmes and the development of climate mainstreaming approaches and tools for "climate screening \&proofing" investments and development interventions. He regularly provides expert input and expertise to climate policy negotiators (on technology transfer, carbon markets, CDM and new market mechanisms), NGOs and various development cooperation partners.

\section{Mr. Pasi Rinne}

Mr. Rinne has profound experience in international environmental governance and diplomacy, environmental management tools, climate change, disaster management, development cooperation, humanitarian assistance and is an internationally well-known policy-maker and environmental thinker. He has actively participated in international discussions on climate adaptation and particularly on potential synergies between mitigation and adaptation. He has personally led numerous carbon management projects for governments, corporations and international organizations such as the United Nations.

\section{Mr. Saleemul Huq}

Mr. Huq is a leading international expert on the links between climate change and sustainable development, and particularly the perspective of developing countries. He has been building negotiating capacity and supporting the engagement of the Least Developed Countries (LDCs) in UNFCCC, including negotiator training workshops for LDCs, policy briefings and support for the Adaptation Fund Board. Vulnerability and adaptation to climate change in LDCs has been at the core of his research. He was the Lead author of the chapter on Adaptation and Sustainable Development in the third assessment report of the Intergovernmental Panel on Climate Change (IPCC) as well as the Lead Author of the chapter on Adaptation and Mitigation in the IPCC's fourth assessment report.

\section{Mr. Svein Tveitdal}

Mr. Tveitdal is a former UNEP director whose portfolio included responsibility for the secretariat to the IPCC and the UNEP relation to UNFCCC. His particular expertise is within bridging the gap between climate science and climate policy, and he has an extensive global and Nordic network related to both science and policy on mitigation and adaptation. Mr. Tveitdal is a Board member of The Norwegian Investment Fund for Developing Countries (Norfund) that is investing in profitable and sustainable enterprises in poor countries. By year end 2011, Norfund had committed investments totaling NOK 7.6 billion in 99 projects, the majority within renewable energy. 